\title{
Spillovers from United States Monetary Policy on Emerging Markets: Different This Time?
}




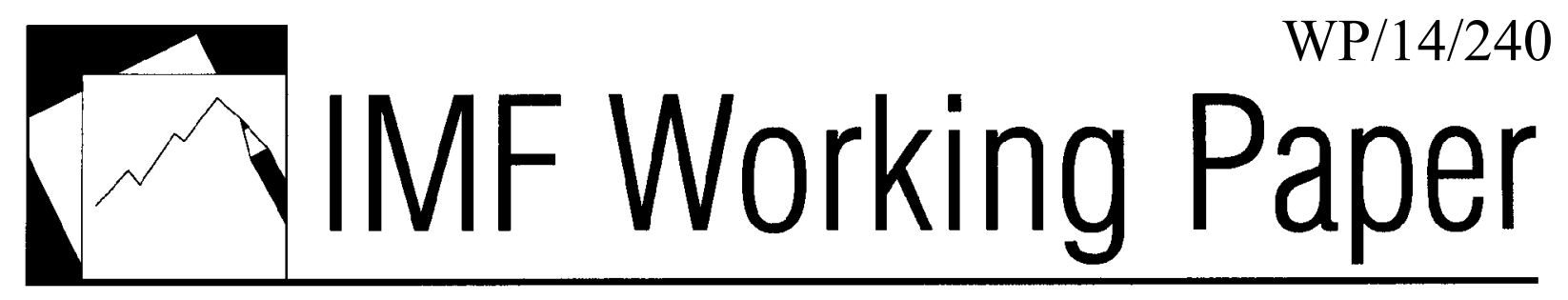

Spillovers from United States Monetary Policy on Emerging Markets: Different This Time?

Jiaqian Chen, Tommaso Mancini-Griffoli, and Ratna Sahay 


\title{
IMF Working Paper
}

\author{
$\mathrm{MCM}$
}

\section{Spillovers from United States Monetary Policy on Emerging Markets: Different This Time? ${ }^{1}$ \\ Prepared by Jiaqian Chen, Tommaso Mancini-Griffoli, and Ratna Sahay}

Authorized for distribution by Ratna Sahay

December 2014

\section{This Working Paper should not be reported as representing the views of the IMF.} The views expressed in this Working Paper are those of the author(s) and do not necessarily represent those of the IMF or IMF policy. Working Papers describe research in progress by the author(s) and are published to elicit comments and to further debate.

\begin{abstract}
The impact of monetary policy in large advanced countries on emerging market economiesdubbed spillovers - is hotly debated in global and national policy circles. When the U.S. resorted to unconventional monetary policy, spillovers on asset prices and capital flows were significant, though remained smaller in countries with better fundamentals. This was not because monetary policy shocks changed (in size, sign or impact on stance). In fact, the traditional signaling channel of monetary policy continued to play the leading role in transmitting shocks, relative to other channels, affecting longer-term bond yields. Instead, we find that larger spillovers stem more from structural factors, such as the use of new instruments (asset purchases). We obtain these results by developing a new methodology to extract, separate, and interpret U.S. monetary policy shocks.
\end{abstract}

\section{JEL Classification Numbers:E4, E5, F3}

Keywords: monetary policy announcements, unconventional monetary policies, spillovers, capital flows, equity markets, bond markets, exchange rates, emerging markets.

Author’s E-Mail Address:jchen@imf.org,tmancinigriffoli@imf.org, rsahay@imf.org

\footnotetext{
${ }^{1}$ Authors are grateful to Olivier Blanchard, Tamim Bayoumi, Hamid Faruquee, Karl Habermeier, Ayhan Kose, André Meier, Gian-Maria Milesi-Ferretti, Mahmood Pradhan, Miguel Segoviano, and Emil Stravrev and IMF seminar participants for useful discussions, to Miguel Savastano for reading the paper very carefully and helping improve its clarity, and to Tomas Mondino for outstanding research assistance.
} 


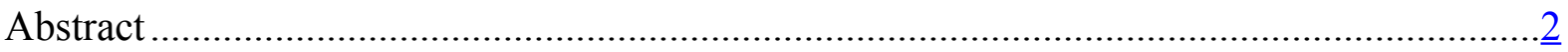

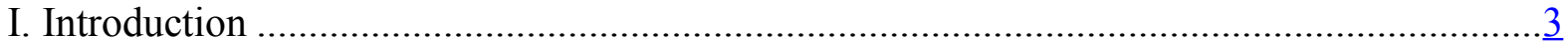

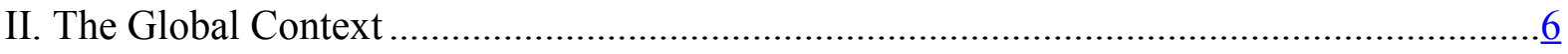

III. Event Study: A New Measure of Monetary Policy Surprise ......................................... $\underline{8}$

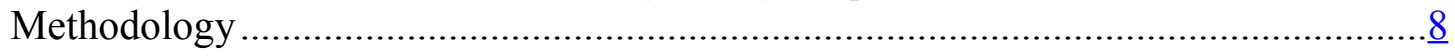

IV. Spillovers of U.S. Monetary Policy: Different over Time?......................................14

V. Spillovers Across Countries_—Why are They Different? ............................................18

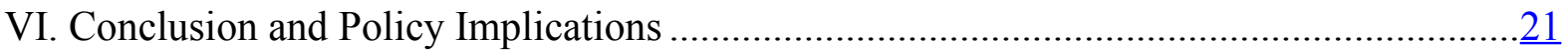

Tables

1. Correlations With Yield Curve Decompositions (Conventional and Unconventional Phases

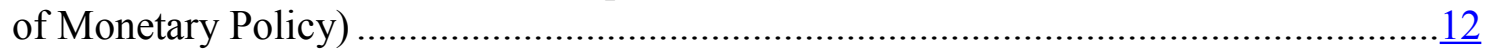

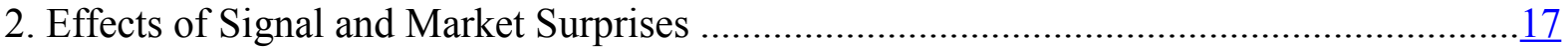

3. Amplifiers or Dampeners of Spillovers, Role of Country Characteristics ........................21

Figures

1. Monetary Policy Accommodation in Advanced Economies: Policy Rates (2000-14), and Central Bank Balance Sheets $(2007-14)$............................................................

2. Equity and Debt Inflows into Emerging Markets ........................................................ $\frac{7}{7}$

3. Large Swings in Asset Prices Follow Tapering Talks: 30-day Standard Deviations of Emerging Markets Equity and Bond Prices (April-September 2013)..........................

4. Correlation Between the Factors and Bonds of Different Maturity (Factor Loadings) ........11

5. Distribution of U.S. Monetary Policy Surprises ............................................................14

6. Asset Price and Capital Flow Movements Across Countries ........................................ 20

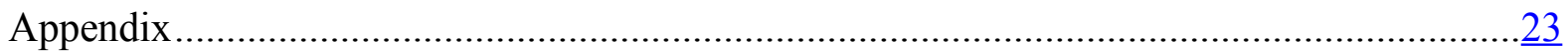

Appendix Tables

1. U.S. Monetary Policy Announcements and Surprises .................................................23

2. Asset Price and Capital Flow Movements Across Time .............................................. 24

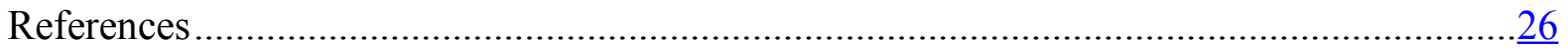




\section{INTRODUCTION}

When the United States (U.S.) sneezes the rest of the world catches a cold. For good reasons, this is not mere folklore. But the 2008 Global Financial Crisis taught us that the world was even smaller than we thought. On the positive side, it helped illustrate the power of U.S. monetary policy to prevent a global depression. However, these policies had important side effects on the rest of the world, most notably on asset prices and capital flows in emerging market economies. Indeed, these effects-coined "spillover effects" - have raised vocal criticism on the part of policy makers in emerging economies, concerned with market volatility and related financial stability risks.

This paper is part of the recent literature that aims to document and explain patterns in the spillovers from U.S. monetary policy to emerging markets (EMs). It does so by asking three questions.

- $\quad$ First, do U.S. monetary policy shocks have significant effects on capital inflows (to both equities and bonds) and asset price movements (equity prices, bond yields and exchange rates) in emerging market economies?

- $\quad$ Second, do these effects differ across different phases of U.S. monetary policyfrom conventional to unconventional? It is important to distinguish between these two phases to understand better the concerns of EMs. After all, easing of monetary policy has occurred on several occasions before the global financial crisis, but has not evoked such strong reactions.

- $\quad$ Third, do the effects of U.S. monetary policy shocks depend on the domestic economic conditions of EMs-namely, do they vary according to the characteristics and policy choices of recipient countries?

With regard to the first question, the paper finds that U.S. monetary policy shocks do affect capital inflows and asset price movements in emerging market economies. This and other results stem from an event analysis covering U.S. monetary policy announcements from January 2000 to March 2014 (inclusive).

On the second question, we find that spillover effects - "per unit" of U.S. monetary policy surprise-are different and stronger during the unconventional monetary policy (UMP) phase (starting in November 2008 with large scale asset purchases), relative to the phase of conventional monetary policy (January 2000 to July 2007). For many assets, spillovers were especially large when the U.S. began discussing the tapering of its asset purchases (May 2013 to March 2014). Spillovers were greatest when announcements surprised markets with information on the future course of policy rates, as opposed to information that affect longer-term U.S. bond yields.

We find that the larger spillover effects during the UMP phase were likely mostly structural, resulting from the new instruments used and the liquidity created. The increase in size and significance of spillovers cannot be explained by a change in the characteristics of the shocks themselves. Spillovers per unit of surprise do not seem to 
depend on the size of the shocks, their sign, or whether they were associated with turning points in the monetary policy stance. The higher market volatility existing at the time of tapering talks amplified spillovers somewhat, though cannot account for the difference with the pre-UMP period.

On the third question, we find that countries with stronger fundamentals are subject to smaller spillovers. Higher real GDP growth and stronger external current account positions, as well as lower inflation and lower shares of local debt held by foreigners significantly dampen spillover effects, especially during the period of unconventional monetary policy. More liquid markets also dampen the effect of spillovers. There is weak evidence that larger markets face larger spillovers, after controlling for market liquidity (as there are two opposing forces at play: larger markets attract more foreign investors who serve to increase volatility, while at the same time these markets tend to be more liquid, which dampens liquidity). U.S. monetary policy surprises associated with changes in the future course of policy induce spillovers that are more differentiated across countries.

The findings in this paper are directly relevant for the conduct of policy in advanced and emerging market economies. Because spillovers from unexpected changes to shortto-medium term policy intentions are greatest, clear central bank communication in advanced economies is key to minimize spillovers. But because spillovers from shocks to the longer-term part of the yield curve are more indiscriminate across countries, central banks should also avoid unsettling term-premia during exit. This paper is also a reminder to emerging market economies of their responsibility to help dampen spillovers in their own countries by strengthening economic fundamentals, policy credibility, and market liquidity.

This paper adds to the recent literature on spillovers of U.S. monetary policy in four ways. First, it introduces a novel measure of U.S. monetary policy shocks by extending widely used methods in the event studies literature. With these, we differentiate between what we call "signal shocks" (which affect expectations of future short-term policy rates), and "market shocks" (which affect longer-term rates through a variety of channels). Controlling for the size of monetary policy shocks (the surprise or unexpected component of announcements) is essential to accurately measure spillover effects. Shocks - and thus effects - can be positive or negative, large or small, depending on market expectations going into an announcement; thus, only effects "per unit of surprise" should be compared directly over time. Second, to our knowledge, this is the first study that compares spillovers between the unconventional monetary policy phase and the conventional phase, before the global financial crisis. The specific measure of surprise we develop in this paper allows us to capture the unexpected component of announcements irrespective of the policy instrument-policy rates or bond purchases. Third, this paper covers multiple aspects of spillovers-over time, countries, and asset prices-which are often dealt with separately in the literature. Finally, this paper places considerable emphasis not just on documenting spillovers, but on explaining empirically the patterns that emerge. 
Papers in the literature on the foreign effects of U.S. monetary policy differ along various dimensions. One is their geographical area of focus. Some papers study spillovers from the U.S. to other advanced economies. Rogers, Scotti, and Wright (2014), Glick and Leduc (2012, 2013), and Neely (2010) find that easing U.S. monetary policy stimulates financial conditions abroad and, in many cases. also weakens the dollar. Neely in particular explores the various channels of transmission. These papers identify U.S. monetary policy shocks using the method in Wright (2012), based on a VAR identified through heteroskedasticity along the lines of Ribogon and Sack (2003 and 2004).

Other papers study spillovers to emerging market economies more widely. But to our knowledge, no other paper compares spillovers to pre-crisis times, with the exception of Gilchrist and others (2014) which focuses only on spillovers to bond yields, and controls for U.S. monetary policy shocks with changes to 1 year bond yields, though finds very similar results (namely that spillovers to EMs only occur in the UMP phase, and affect long-term bonds). Most papers do not control for U.S. monetary policy shocks, except for Bowman, Londoño, and Sapriza (2014) which also follows Wright (2012), and Hausman and Wongswan (2011) which adopts the GSS $(2005,2007)$ methodology though as applied to pre-UMP sample. Remaining papers mostly focus on the initial phase of UMP, before the Fed's taper talk: DePooter, Robitaille and Zdinak (2014), Moore, Nam, Suh, and Topper (2013), and Chen, Filardo, He, and Zhu (2012), as well as Ahmed and Zlate (2013) and Fratzscher, LoDuca, and Straub (2013) which study the effects of actual asset purchases, instead of policy announcements. A few papers narrow-in on the taper talk episode of the summer of 2013, such as Basu, Eichengreen and Gupta (2014) and Mishra, Moriyama, N’Diaye, and Nguyen (2014).

All papers find some evidence of spillovers. An easing (tightening) of U.S. monetary policy seems to boost (dampen) foreign asset prices, with some variation across the types of assets (most papers focus on bond markets). There appears to be, instead, some contradiction in the findings with regard to the role played by domestic country fundamentals. Basu, Eichengreen, and Gupta (2014) find that better fundamentals (government deficit, public debt, foreign reserves, growth) did not dampen spillovers, contrarily to Mishra, Moriyama, N’Diaye, and Nguyen (2014), and Bowman, Londoño, and Sapriza (2014). Differences may come from whether (and how) papers control for the size and sign of U.S. monetary policy shocks. It is also not clear what role domestic policies can play in attenuating spillovers when these occur. Fratzscher, LoDuca and Straub (2013) find no evidence that foreign exchange (FX) or capital account policies helped contain spillovers, while Moore, Nam, Suh, and Topper (2013) point to weak evidence that flexible exchange rate regimes help shield bond yields from foreign monetary policy shocks.

The rest of the paper is structured as follows: Section II reviews the global context in which spillovers occurred. Section III introduces our new measure of monetary policy surprise, and contrasts the method and findings in this paper to those in the literature. The section continues by illustrating the estimated U.S. monetary policy shocks. Section IV gauges spillover effects over different phases of U.S. monetary policy, and aims to explain the variation over time. Section $V$ documents and explains the variation 
in spillovers across recipient countries, depending on country characteristics. The final section concludes and extracts policy implications.

\section{The Global Context}

No doubt the world would have been different without unconventional monetary policies. Central banks in advanced economies had to respond to the global financial crisis on a scale commensurate with the shock to those economies. Interest rates were brought to nearly zero in record time, and have been kept at that level for several years now. Even more strikingly, the asset purchase programs massively increased central bank balance sheets. These well known facts are illustrated in Figure 1.

Figure 1. Monetary Policy Accommodation in Advanced Economies: Policy Rates (2000-14), and Central Bank Balance Sheets (2007-14)
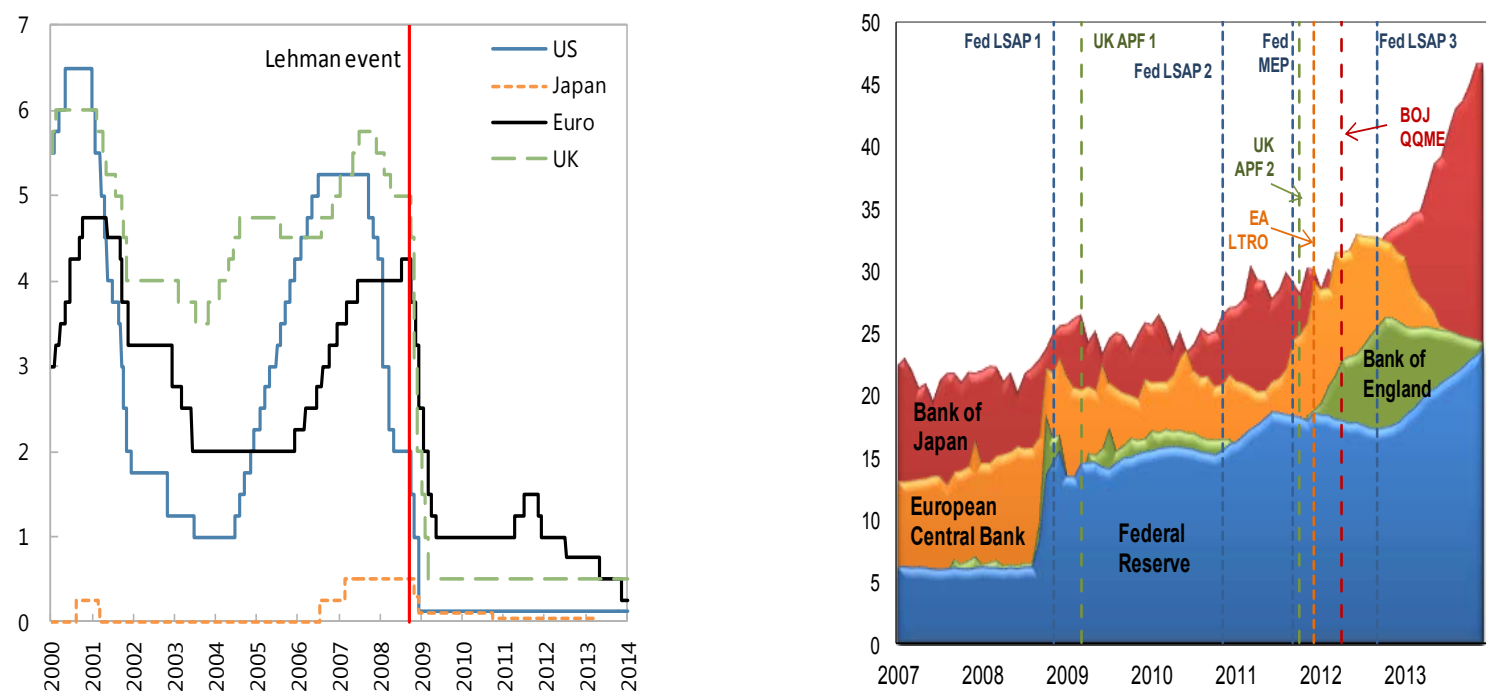

Sources: Board of Governors of the Federal Reserve System, ECB, Bank of England, Bank of Japan, Haver analytics, and authors' calculations. Policy rates are in percent, and balance sheet sizes in percent of GDP.

As the period of accommodation continued, policy makers in EMs began to voice concerns. They noted that the monetary expansion in advanced economies had spilled over across the globe and into their economies. There was a surge in capital inflows, especially towards debt instruments (Figure 2), their currencies appreciated, and their asset prices rose rapidly. EMs' policymakers worried about painful sectoral adjustments due to large shifts in the exchange rate and balance sheet mismatches, as well as rising vulnerabilities in their financial systems as equity and bond prices boomed, credit bubbles built up, and corporates built excessive leverage. Many of them recalled earlier episodes of capital inflow surges, where hiking interest rates to dampen bubbles - especially without serious inflationary pressures - did not prove to be a good option as it served to attract further capital inflows and stoke the currency's appreciation. 
Figure 2. Equity and Debt Inflows into Emerging Markets (2002-12, in billions of U.S. dollars, cumulative)

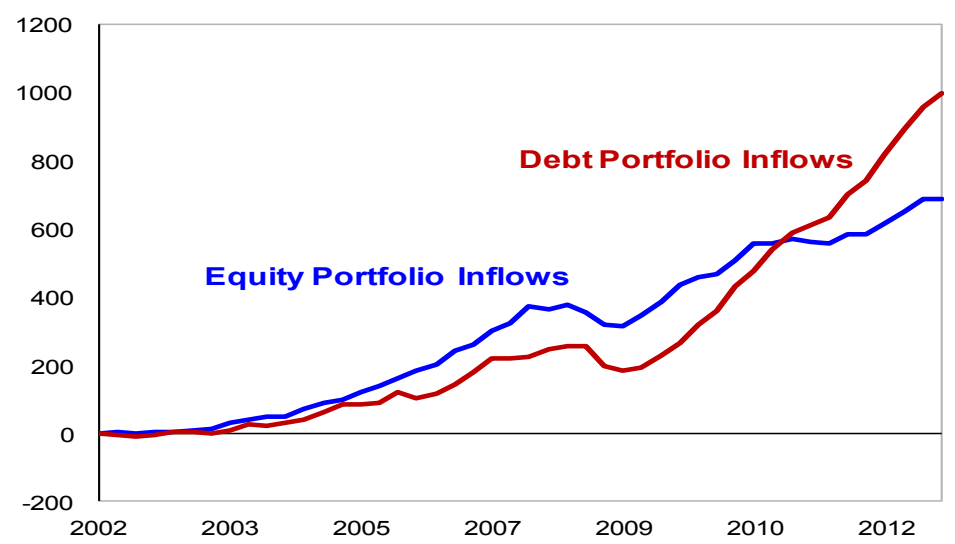

Source: International Financial Statistics.

An even sharper wave of criticism followed the Fed's "taper talk." When the possibility of reining in unconventional monetary policies was first mentioned by former Fed Chairman Bernanke in May 2013, there was a spike in market volatility in EMs (Figure 3).

Figure 3. Large Swings in Asset Prices Follow Tapering Talks: 30-day Standard Deviations of Emerging Markets Equity and Bond Prices (April-September 2013)

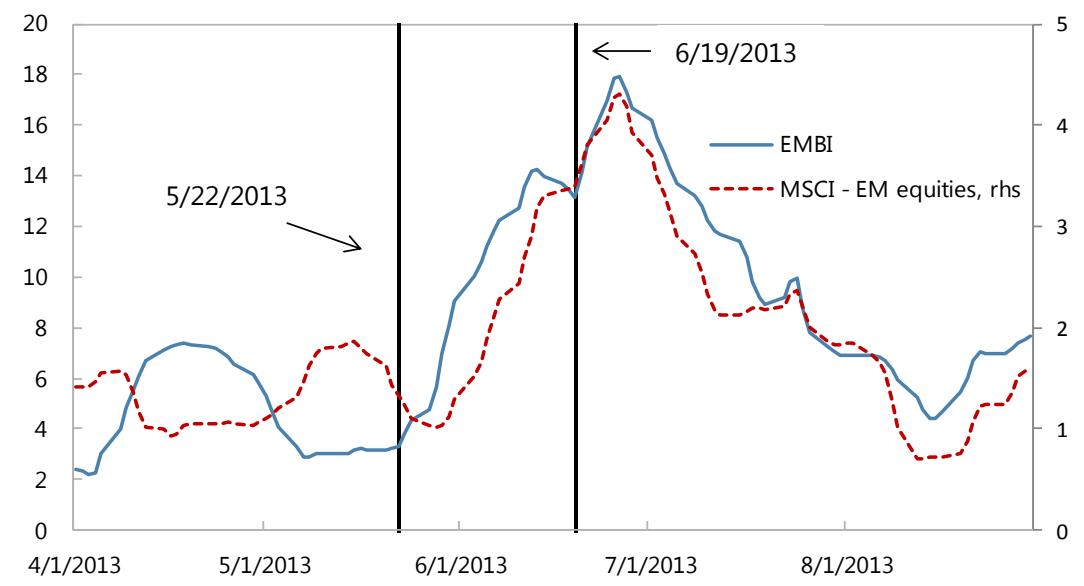

Source: Bloomberg.

Note: MSCI Emerging Markets Index (MSCl) for equities, and JP Morgan Emerging Markets Bond Index (EMBI). 
This recent episode rekindled longstanding debates on the optimal policy reactions, both in advanced and emerging market economies, to market volatility caused by major shifts in monetary policy. Various proposals have been put forward. One focuses on dampening the original shock, through clearer communication from central banks in advanced economies. Another one highlights the strengthening of fundamentals and the resilience of the financial systems in EMs to external shocks with appropriate macroeconomic policies and prudential regulations. Third, there is growing recognition that foreign exchange interventions in some cases capital flow management measures, may be useful to complement macro-economic adjustments. Last, but not least, the episodes rekindled the debate on international policy cooperation, to internalize the negative spillovers from unilateral policy action, and maximize global welfare.

The empirical analysis that follows sheds light on these issues by improving our understanding of the nature of spillovers - their size, origins, and the factors that either amplify or dampen them - as well as the source of the problem in EMs, whether domestic or imported from abroad.

\section{Event Study: A New Measure of Monetary Policy Surprise}

\section{Methodology}

As noted, we use an event study methodology to isolate the impact and direct effects of U.S. monetary policy shocks on asset prices and capital flows in EMs. Event studies offer a simple identification strategy. The dominant shock on event days is taken to be the monetary policy announcement in advanced economies, and the impact effect on financial markets is assumed to be felt within a 2-day window, as adopted in this paper. A longer window would pick up the effects of other shocks on financial markets, while a shorter window might not pick-up the full effect of the monetary policy shock, given non-overlapping market opening hours around the world. A shortcoming of event studies is that they are not able to capture persistence effects. Testing for persistence would require a more fully specified econometric analysis, which, in the case of financial variables, usually suffers from a low fit. This is outside the scope of this paper.

A central ingredient to the event analysis is the surprise component of monetary policy announcements. This allows us to compare effects per a standard unit of surprise. If an announcement - albeit substantial - is fully anticipated, it will have no effect on market prices or portfolio reallocation; the announcement will already have been priced in. But it would be wrong to conclude that policy is ineffective, based on the absence of impact effect. Even more starkly, an announcement that tightens the monetary policy stance, could generate a loosening shock if markets had anticipated a larger tightening. The ensuing market response alone would suggest that that policy announcement is self-defeating, which again would be an incorrect inference. Thus, to correctly estimate the effects of monetary policy, it is imperative to measure the surprise component of announcements, and not just to use dummy variables to isolate event (announcement) days, as is common in the literature. In fact, we find that results differ markedly if we do not control for the sign and magnitudes of monetary policy shocks. 
To measure monetary policy surprises, we extend methods commonly used in the literature on event studies in monetary policy. ${ }^{2}$ The monetary policy surprise is often defined as the difference between the yield of the next expiring futures on Federal Funds, taken just before an FOMC announcement, and the target Federal Funds rate actually announced. The interpretation is simple and unequivocal: the central bank can surprise markets with its choice of policy rate.

But announcements can surprise along other dimensions, argue Gurkaynak, Sack and Swanson (2005 and 2007, henceforth, GSS; see Woodford, 2012, for a summary). Announcements are not just about punctual changes in interest rates, which by themselves have little impact on economic behavior. Announcement affect longer term rates-more relevant for economic decisions - through the signals they provide about future policy intentions. This is done through various means, such as verbal statements and accompanying forecasts or other official publications.

GSS $(2005,2007)$ capture this additional dimension of monetary policy shocks using factor analysis. Specifically, they extract two factors from the 1-24 month yield curve to isolate the Bernanke and Kuttner surprise on the immediate policy rate (the timing factor), and the surprise relative to the path of interest rates up to two years ahead (the path factor). It turns out that the path factor explains nearly all the variation in expectations of Federal Funds rates four or more quarters into the future, and is highly correlated with a variety of asset prices, including bond yields. Similar results are obtained by Campbell, Evans, Fisher and Justiniano (2012). It is the path factor, it seems, that accounts for most of the effects of monetary policy.

Much like GSS $(2005,2007)$ built on Bernanke and Kuttner $(2003)$, we aim to capture further dimensions, or information content, of monetary policy announcements. In addition to information on current rates and short-term policy intentions, monetary policy announcements can convey information about the supply of bonds that will be available to private investors, and longer-term risks to (or uncertainty about) growth, inflation and changes to central bank preferences and objectives. This is especially relevant for the unconventional monetary policy followed in recent years, where the instruments of monetary policy were expanded to include forward guidance and bond purchases. Surprises along these dimensions are likely to be reflected in longer-term bond rates.

Recent studies have found evidence of a widening of the monetary policy transmission mechanism since the adoption of unconventional instruments. Those studies show that the signaling channel continued to play an important role, but over longer horizons than before, in line with the extended forward guidance that accompanied asset purchase announcements. ${ }^{3}$ The studies also found evidence of the portfolio rebalancing channel, as bond purchases

\footnotetext{
${ }^{2}$ The pioneering work was undertaken by Bernanke and Kuttner (2003), and later expanded by Rigobon and Sack (2003 and 2004).

${ }^{3}$ See works of Bauer and Rudebusch (2014), Bauer and Neely (2013), and Rudebusch and Christensen (2013), among others.
} 
decreased term premia of longer-term bonds, by lowering the price of risk, and forcing investors to hold a larger amount of relatively less attractive assets. ${ }^{4}$ Our event analysis extends the logic and method of GSS $(2005,2007)$ to pick up the additional dimensions of monetary policy announcements by extracting two factors from changes in U.S. bond yields across the yield curve from 1 year to 30-year maturities (a much longer horizon than considered by GSS). These two factors explain 99 percent of the variation in U.S. bond yields, with a third factor adding very little. ${ }^{5}$

We then rotate the two factors extracted to find a plausible interpretation for each of them. We use the common Varimax rotation method that maximizes the sum of the variance of the squared loadings. ${ }^{6}$ Intuitively, this occurs when any given bond-say a bond of 3-year maturity - has a high loading on a single factor but low loadings on the remaining factors.

The method allows for a very clean separation-and interpretation-of the two factors. As shown in Figure 4 the first factor has very high loadings on longer-term bonds of 5 to 30 years, and the second factor has very high loadings on shorter-term bonds of 1 to 3 - years, arguably up to 5 years.

We call the first factor the market factor. Given its high correlation with longer-term bonds, we view this factor as encompassing the portfolio rebalancing channel of monetary policy, as well as any other information the Fed communicates about the supply of bonds that will be available to private investors, and longer-term risks to (or uncertainty about) growth, inflation and changes to central bank preferences and objectives.

We call the second factor the signal factor, which we assume to be correlated to the more traditional signaling channel of monetary policy (namely the information the Fed

\footnotetext{
${ }^{4}$ D’Amico, English, Lopez-Salido, and Nelson (2012), and Krishnamurthy and Vissing-Jorgensen (2011), among others, provide a useful overview of the various channels of transmission of unconventional monetary policy.

${ }^{5}$ Rather than trying to capture the timing factor of GSS (which, as discussed earlier, does not explain much of the variation in asset prices, as opposed to the path factor), we try to relate the two factors we extract with (i) the signaling channel of monetary policy (similar to the path factor in GSS); and (ii) other channels and information that are likely to affect longer-term interest rates and term premia. We use data on daily U.S. bond prices from Bloomberg. Changes in prices are computed as the difference between the close of the announcement day to the close of the day prior.

${ }^{6}$ The Varimax method is an orthogonal rotation of the factor axis, leaving the factors independent. Factors make up a subspace onto which the data vectors are projected. The projection vectors are described as linear combination of the factor vectors, where the weights on the factor vectors are the loadings. Thus, any rotation of the factor vectors on the fitting hyperplane can be used, with different loadings, to define the projection vector. The issue at hand, as pursued in this paper, is to find the rotation that yields the most intuitive interpretation of the factors. See Gorsuch (1983) or Anderson (1984) for a detailed treatment of factor analysis. In short, we estimate the unobserved factor matrix $F$ (Txk with $k$ the number of factors) given by $X=F A+B$, where $X$ is a $T x n$ matrix of changes in bond yields over $n(>k)$ maturities and $T$ observations, $A$ is a $k x n$ matrix of factor loadings, and $B$ is a Txn matrix of white noise disturbances. More details are also given in GSS (2005).
} 
provides on future short-term policy rates). Loadings on this factor are high relative to bonds with a maturity of up to 3-5 years, the maximum period over which central banks might be expected to commit to a course of policy.

Figure 4. Correlation Between the Factors and Bonds of Different Maturity (Factor Loadings)

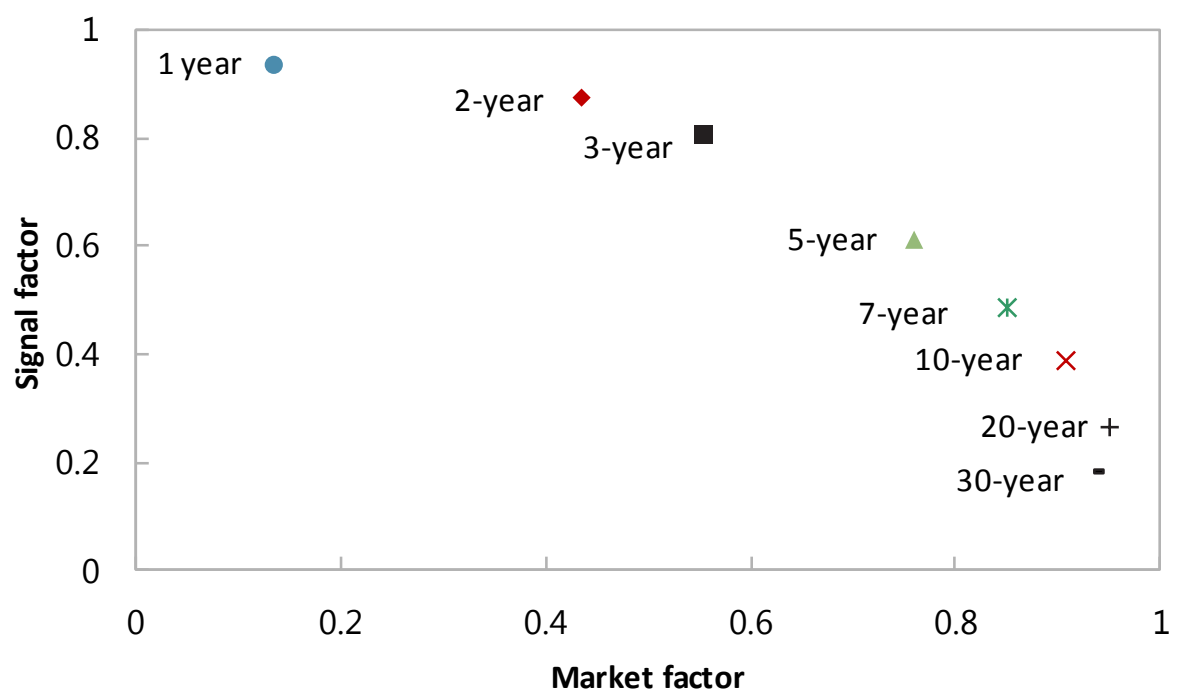

Source: Authors' calculations.

Note: As explained in the text, the market factor corresponds to the first factor, and the signal factor to the second.

The interpretation of each factor appears robust. The signal factor is highly correlated to riskneutral expectations of future short-term rates extracted from term structure models (commonly thought to react to the signaling channel of monetary policy). On the other hand, the market factor closely tracks the term-premium component (associated with the portfolio rebalancing channel of monetary policy). Table 1 shows bivariate correlations of each of the factors with yield curve components at different maturities, for the conventional monetary policy phase (CMP phase for short, from February 2000 to July 2008, just before the Lehman Brother's event), and for the unconventional monetary policy phase (UMP, from November 2008, the first QE1 announcement, to the end of sample in March 2014).7

\footnotetext{
${ }^{7}$ Our results are robust to the particular specification of the underlying affine term-structure model Table 1 shows results for the Joslin, Singleton and Zhu (2011) specification. Those related to the Kim and Wright (2005) and Adrian, Crump and Moench (2013) specifications are available upon request.
} 


\section{Table 1. Correlations With Yield Curve Decompositions (Conventional and Unconventional Phases of Monetary Policy)}

\begin{tabular}{|c|c|c|c|c|c|c|}
\hline & 1 year & 2 year & 3 year & 5 year & 7 year & 10 year \\
\hline \multicolumn{7}{|c|}{ CMP Phase (Feb. 2000-Jul. 2008) } \\
\hline & \multicolumn{6}{|c|}{ Expected short rate } \\
\hline \multirow[t]{2}{*}{ Signal factor } & 0.96 & 0.97 & 0.97 & 0.96 & 0.96 & 0.96 \\
\hline & \multicolumn{6}{|c|}{ Term premium } \\
\hline Market factor & 0.22 & 0.83 & 0.85 & 0.81 & 0.75 & 0.71 \\
\hline \multicolumn{7}{|c|}{ UMP Phase (Nov. 2008-Apr. 2014) } \\
\hline & \multicolumn{6}{|c|}{ Expected short rate } \\
\hline Signal factor & 0.63 & 0.81 & 0.86 & 0.90 & 0.91 & 0.92 \\
\hline & \multicolumn{6}{|c|}{ Term premium } \\
\hline Market factor & 0.51 & 0.86 & 0.92 & 0.96 & 0.98 & 0.99 \\
\hline
\end{tabular}

Source: Authors' calculations.

Note: The term premium and expected short rates component of U.S. 10-year bond yields are estimated following Joslin, Singleton and Zhu (2011).

Despite the very high correlations with components of the yield curve extracted from affine term structure models, the two factors identified in the analysis differ in important ways. They are orthogonal to one another and comparable in size, a characteristic that facilitates empirical analysis. In addition, they are not affected by model specification (as discussed in Bauer and Rudebusch, 2014, different affine term structure model specifications can lead to rather different yield curve decompositions).

\section{Key Patterns of monetary policy surprises}

We look for patterns across three general phases of U.S. monetary policy: the conventional monetary policy phase, or CMP (from January 2000 to July 2007), the UMP phase coinciding with announcements of bond purchase programs (November 2008 to May 2013), and the UMP phase from May 2013 until March 2014 when talk of tapering started. We refer to the first as UMP phase as UMP-P ("P" for purchases), and to the second as UMP-T ("T" for tapering).

U.S. monetary policy surprises, broken down into signal and market factors as defined in this paper, are shown in Figure 5. Each bar represents an FOMC announcement. Bars are comparable, as factors are by construction standardized measures, and orthogonal to one another. Positive bars indicate announcements surprising markets on the hawkish side (tightening surprises), and negative bars represent dovish or loosening surprises. We exclude from the chart, and dataset, days for which both the signal and market surprises were in the smallest 10 percent range of their respective 
distributions. This filter helps narrow the set of shocks to those most likely to be a main source of market movements. Applying this filter leaves us with 74 announcement dates over the CMP period, 42 over the UMP-P period and 9 over the UMP-T period.

A key fact that emerges from Figure 5 is that the sign and size of U.S. monetary policy surprises changed over time. During the CMP phase, market and signal surprises were approximately of equal size, and mostly centered around zero, with a slight negative skew for signal surprises (in line with a widely observed regularity that monetary policy more often surprises with cuts, rather than hikes, as a result of unexpected negative macroeconomic, financial or political shocks).

Market surprises grow to be noticeably larger during the UMP-P and UMP-T phases. And signal surprises shrink to levels smaller even than market surprises, suggesting that unconventional monetary policies primarily conveyed information affecting longer-term bonds and term premia. UMP-P surprises, as expected, have a negative skew, since announcements aimed to loosen monetary conditions, sometimes aggressively. UMP-T surprises are much more balanced, with the May and June 2013 announcements representing strong tightening shocks, countered by the September 2013 decision to postpone tapering having surprised markets on the dovish side. Lastly, and importantly, average and maximum UMP-T surprises are smaller than UMP-P surprises, for both signal and market factors. This last result is surprising, as it goes counter to the general perception following the May 2013 tapering announcement.

Finally, to further explore the distribution of surprises, we dwell on a few well known announcements. These are described, along with their sign and magnitude, in Table A1 in the Appendix, alongside the corresponding market and signal surprises. The same features as described above stand out. Market surprises are larger in the UMP phase, and surprises of more aggressive easing (or less aggressive cuts) are negative, while those of less aggressive easing (or more aggressive hikes) are positive. Even some of the announcements meant to ease the policy stance at the heart of the crisis had positive surprises, to the extent that a more aggressive announcement was expected. The exercise confirms the importance of controlling for the surprise component of monetary policy announcements, and investigating the market factor in addition to the more common signal factors. 
Figure 5. Distribution of U.S. Monetary Policy Surprises

Market factor

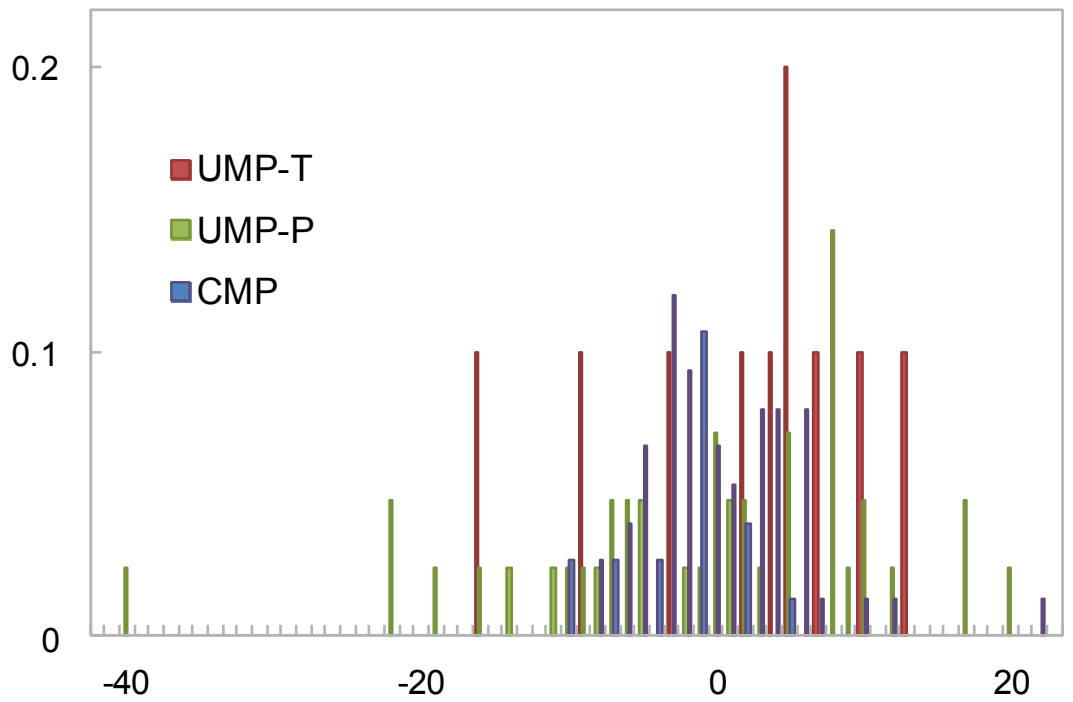

Signal factor

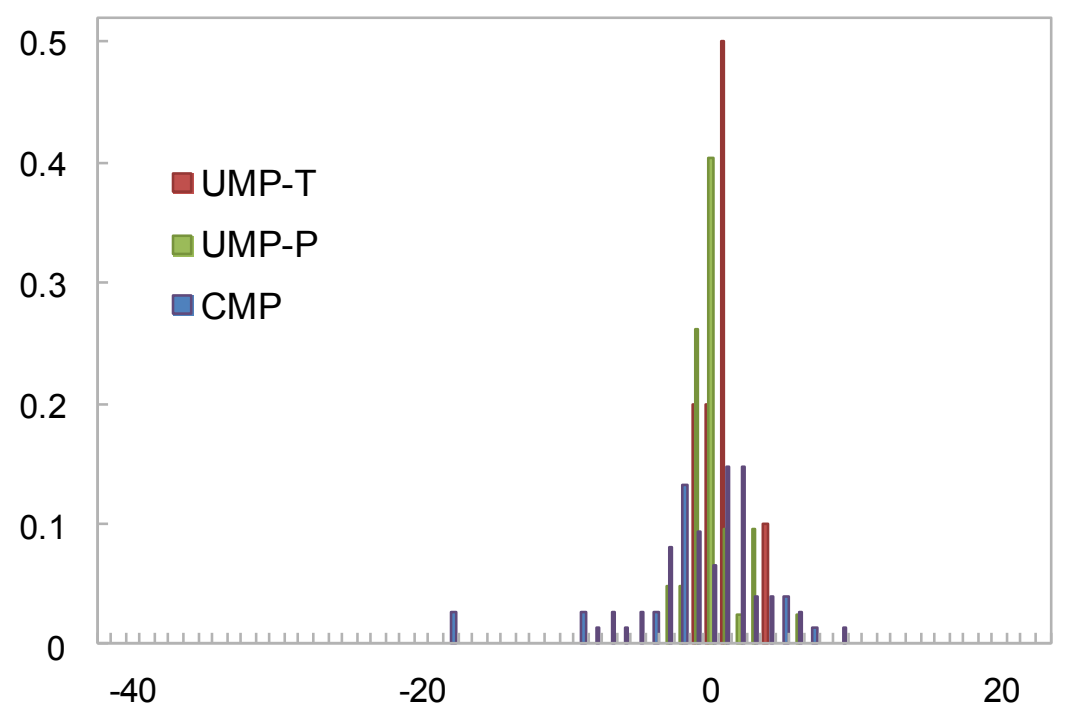

Source: Authors' calculations.

\section{SPILlovers OF U.S. Monetary POlicy: Different OVER Time?}

This section tries to ascertain whether correlations between U.S. monetary policy surprises and EM market reactions in the UMP phases differed substantially to those in the CMP phase. The question is important for two reasons. First, to gauge whether the effects of U.S. monetary policy shocks on the rest of the world differ according to the policy instruments used to provide more or less accommodation. And second, within 
the phase of unconventional policy, to see whether tapering shocks differ from shocks associated with the expansion of UMP programs.

To address this question, we estimate a panel regression using data for 21 emerging market economies. ${ }^{8}$ The regression seeks to identify the effects of U.S. monetary policy surprises on asset prices and capital flows in EMs. The regression specification is:

$$
\Delta y_{i t}=\alpha_{i}+\beta_{1} m 1+\beta_{2} m 2+\varepsilon_{i t}
$$

where $y_{i t}$ is the asset price or capital flow for country $i$ in period $t$, and $m 1$ and $m 2$ are the surprises in U.S. monetary policy corresponding to market and signal factors, respectively. Table 2 reports the results from the estimation, and Figure A1 in the Appendix illustrates the changes in asset prices and capital flows in the 2-day windows following each FOMC announcement over the sample.

Results suggest that U.S. monetary policy surprises did not have significant spillover effects during the CMP phase. Except for signal surprises on equity flows, none of the estimated coefficients are statistically significant in this phase.

Spillover effects per unit of U.S. monetary policy surprise grew statistically in the UMP-P phase. Effects from signal surprises in particular were larger and different in the UMP-P relative to those in the CMP phase, at the 1 and 5 percent level of significance. But market surprises only differed at the 10 percent level of significance, and indeed had small spillovers in the UMP-P phase.

Results for the regressions on UMP-T shocks are again different. The coefficients for both signal and market surprises are statistically significant, and different at the $1-5$ percent level of significance from those in the regressions for UMP-P and CMP shocks. Effects from market surprises grow notably relative to equivalent UMP-P shocks. Signal surprises have larger effects on bond yields and equity flows, but smaller effects on equity prices and exchange rates relative to the UMP-P phase.

The estimated coefficients on U.S. monetary policy surprises in the UMP-P and UMP-T phases have the expected sign. Negative (loosening) surprises - whether through the signal or market factor - are associated with increases in equity prices in emerging market economies, lower bond yields, and stronger currencies. They are also generally correlated with portfolio flows into equities, while bond flows remain insignificant. These results are consistent with those in the literature surveyed earlier. ${ }^{9}$

\footnotetext{
${ }^{8}$ Countries are: Brazil, Chile, China, Colombia, Hungary, India, Indonesia, Israel, Korea, Malaysia, Mexico, Peru, Philippines, Poland, Romania, Russia, Singapore, South Africa, Taiwan POC, Thailand, and Turkey. These were chosen on the basis of sufficiently liquid markets, integration with international financial markets, and data availability.

${ }^{9}$ Results differ markedly if we do not control for the sign and magnitude of monetary policy surprises. When a dummy is used, as is common in the literature, to isolate FOMC announcement dates (as opposed to days without announcements), results suggest that spillovers are on average higher during the CMP period, signs on coefficients are at times contradictory (such as on equity and bond flows), signs on coefficients awkwardly reverse between the UMP-P and UMP-T periods, and domestic country characteristics almost never have an
} 
In the three samples, the estimated coefficients of signal surprises are consistently larger and more statistically significant than those of market surprises. Moreover, as noted earlier, effects of signal surprises are more often significantly different to those of conventional monetary policy. Because factors are orthogonal and normalized, the size of coefficients can be compared. A plausible reason for this finding is that signaling surprises are perceived by the public as longer lasting or more closely correlated with macro fundamentals than market surprises. The result is similar to the one in Chen, Mancini-Griffoli, and Saadi-Sedik (2014, forthcoming) where the signaling channel of monetary policy in the U.S. and U.K. is found to have stronger effects on growth and inflation than the portfolio rebalancing channel. Stein (2013) hypothesizes that changes in term premia induce firms to optimize the term structure of their debt, but not to engage in productive investments.

Why did spillovers per unit of surprise change over phases of U.S. monetary policy? And why did they become larger during the UMP-T phase relative to the other phases?

There are at least two hypotheses that can be put forward. The first has to do with the type of shocks. Monetary policy shocks that mark turning points in the monetary policy stance may be associated with larger spillovers. Another possibility is that positive shocks have larger spillovers than negative shocks. Alternatively, larger shocks might have disproportionately larger spillovers; but we do not investigate this hypothesis further as it does not have grounding in the data patterns reviewed earlier (UMP-T shocks were smaller on average than UMP-P shocks).

To investigate the turning point hypothesis, we include a dummy variable in the baseline regression (as shown below) that takes a value of 1 on announcements that indicate a turning point in the U.S. monetary policy stance. There are ten such instances in the sample. ${ }^{10}$ Regression results show that none of the coefficients on the dummy variables capturing turning points are statistically significant, and that other coefficients do not change significantly. (The focus is on $\gamma_{1}, \gamma_{2}$ and $\gamma_{3}$, in the following regression.)

$$
\Delta y_{i t}=\alpha_{i}+\beta_{1} m 1+\beta_{2} m 2+\gamma_{1} D_{t}+\gamma_{2} D_{t} m 1+\gamma_{3} D_{t} m 2+\varepsilon_{i t}
$$

We follow the same strategy to investigate whether positive or negative shocks have effects that are significantly larger than average. Once again, results are inconclusive. Relevant dummy coefficients are nearly always insignificant, except for some isolated instances.

effect on spillovers (a topic investigated in the next section of this paper). These results reinforce the importance of controlling for the surprise component of monetary policy announcements.

${ }^{10}$ These are January 2001 (start of the cut to very low rates), December 2001 (rates at 40 year lows), June 2004 and June 2006 (start and end of the interest rate normalization), September 2007 (start of aggressive cuts towards zero lower bound), November 2008 (start of MBS purchases), March 2009 (start of bond purchases), September 2012 (explicit forward guidance extended), and May and June 2013 (first discussions of tapering). 
Table 2. Effects of Signal and Market Surprises

\begin{tabular}{|c|c|c|c|c|c|c|c|c|c|c|c|c|c|}
\hline \multirow[b]{2}{*}{ VARIABLES } & \multicolumn{3}{|c|}{ Equity } & \multicolumn{3}{|c|}{ Bond Yield } & \multicolumn{3}{|c|}{ Exchange Rate } & \multicolumn{3}{|c|}{ Equity Flows } & \multirow[b]{2}{*}{$\mathrm{CMP}$} \\
\hline & $\mathrm{CMP}$ & UMP-P & UMP-T & $\mathrm{CMP}$ & UMP-P & UMP-T & CMP & UMP-P & UMP-T & CMP & UMP-P & UMP-T & \\
\hline & & & \multicolumn{11}{|c|}{ Recression 1: U.S. monetarv policv surprises } \\
\hline $\mathrm{m} 1$ & $0.02^{*}$ & -0.00 & $-0.11^{\star \star \star \star}$ & -0.00 & $0.00^{* * *}$ & $0.01^{\star \star *}$ & -0.00 & $0.01^{* *}$ & $0.07^{\star \star \star *}$ & 0.01 & $0.01^{\star *}$ & -0.01 & 0.07 \\
\hline & $(0.01)$ & $(0.00)$ & $(0.02)$ & $(0.00)$ & $(0.00)$ & $(0.00)$ & $(0.00)$ & $(0.00)$ & $(0.01)$ & $(0.01)$ & $(0.01)$ & $(0.02)$ & $(0.05)$ \\
\hline $\mathrm{m} 2$ & $0.03^{*}$ & $-0.48^{* \pi *}$ & $-0.18^{\star \star \star *}$ & 0.00 & $0.01^{* \star \star *}$ & $0.06^{\star \star * *}$ & 0.02 & $0.35^{\star \star \star \star}$ & $0.12^{* \star \star}$ & $0.03^{\star *}$ & $-0.16^{\star \star}$ & $-0.43^{* *}$ & -0.08 \\
\hline & $(0.02)$ & $(0.05)$ & $(0.05)$ & $(0.00)$ & $(0.00)$ & $(0.02)$ & $(0.01)$ & $(0.06)$ & $(0.04)$ & $(0.01)$ & $(0.06)$ & $(0.20)$ & $(0.06)$ \\
\hline Constant & $\begin{array}{l}0.38^{\star \star \star *} \\
(0.01)\end{array}$ & $\begin{array}{l}0.07^{\star \star *} \\
(0.03)\end{array}$ & $\begin{array}{l}0.12^{\star \star} \\
(0.04)\end{array}$ & $\begin{array}{c}-0.02^{\star * \star} \\
(0.00)\end{array}$ & $\begin{array}{l}-0.00^{*} \\
(0.00)\end{array}$ & $\begin{array}{l}0.03^{\star \star \star *} \\
(0.00)\end{array}$ & $\begin{array}{c}-0.10^{* \star \star \star} \\
(0.01)\end{array}$ & $\begin{array}{l}0.21^{\star \star \star} \\
(0.03)\end{array}$ & $\begin{array}{l}0.16^{\star \star *} \\
(0.02)\end{array}$ & $\begin{array}{l}0.19^{\star \star *} \\
(0.02)\end{array}$ & $\begin{array}{l}0.07^{\star \star} \\
(0.03)\end{array}$ & $\begin{array}{c}-0.38^{\star \star \star *} \\
(0.01)\end{array}$ & 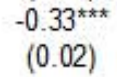 \\
\hline Observations & 1,306 & 812 & 175 & 993 & 726 & 140 & 1,303 & 804 & 175 & 1,031 & 713 & 143 & 81 \\
\hline R-squared & 0.01 & 0.14 & 0.25 & 0.00 & 0.06 & 0.20 & 0.01 & 0.20 & 0.26 & 0.01 & 0.03 & 0.03 & 0.04 \\
\hline \multirow[t]{2}{*}{ Number of countries } & 21 & 21 & 21 & 17 & 18 & 18 & 21 & 21 & 21 & 19 & 18 & 18 & 5 \\
\hline & & & \multicolumn{11}{|c|}{ Recression 2: ИX } \\
\hline Change in $\mathrm{VX}$ & $\begin{array}{c}-0.11^{\star * *} \\
(0.01)\end{array}$ & $\begin{array}{c}-0.10^{\star \star \star} \\
(0.01)\end{array}$ & $\begin{array}{c}-0.07^{\star \star \star *} \\
(0.01)\end{array}$ & $\begin{array}{l}0.00^{\star \star} \\
(0.00)\end{array}$ & $\begin{array}{c}0.00 \\
(0.00)\end{array}$ & $\begin{array}{l}0.01^{\star \star} \\
(0.00)\end{array}$ & $\begin{array}{l}0.03^{\star \star \star} \\
(0.00)\end{array}$ & $\begin{array}{l}0.04^{* * *} \\
(0.01)\end{array}$ & $\begin{array}{l}0.03^{\star \star \star} \\
(0.01)\end{array}$ & $\begin{array}{c}-0.02^{\star \star *} \\
(0.01)\end{array}$ & $\begin{array}{l}-0.00 \\
(0.01)\end{array}$ & $\begin{array}{c}-0.06^{* * *} \\
(0.02)\end{array}$ & $\begin{array}{c}0.02 \\
(0.02)\end{array}$ \\
\hline Constant & $\begin{array}{l}0.13^{\star \star \star *} \\
(0.02)\end{array}$ & $\begin{array}{c}0.04 \\
(0.03)\end{array}$ & $\begin{array}{c}-0.15^{\star \star \star *} \\
(0.00)\end{array}$ & $\begin{array}{c}-0.02^{\star \star \star \star} \\
(0.00)\end{array}$ & $\begin{array}{c}-0.01^{* \star * *} \\
(0.00)\end{array}$ & $\begin{array}{l}0.03^{* * *} \\
(0.00)\end{array}$ & $\begin{array}{c}-0.06^{\star \star \star} \\
(0.01)\end{array}$ & $\begin{array}{l}0.14^{* * *} \\
(0.02)\end{array}$ & $\begin{array}{l}0.33^{\star \star \star *} \\
(0.00)\end{array}$ & $\begin{array}{l}0.10^{* * \star} \\
(0.02)\end{array}$ & $\begin{array}{l}0.11^{* \star *} \\
(0.03)\end{array}$ & $\begin{array}{c}-0.36^{\star * \star *} \\
(0.00)\end{array}$ & $\begin{array}{c}-0.28^{\star * \star \star} \\
(0.02)\end{array}$ \\
\hline Observations & 1,306 & 812 & 175 & 993 & 726 & 140 & 1,303 & 804 & 175 & 1,031 & 713 & 143 & 81 \\
\hline R-squared & 0.12 & 0.15 & 0.07 & 0.01 & 0.00 & 0.06 & 0.04 & 0.08 & 0.04 & 0.01 & 0.00 & 0.06 & 0.01 \\
\hline \multirow[t]{2}{*}{ Number of countries } & 21 & 21 & 21 & 17 & 18 & 18 & 21 & 21 & 21 & 19 & 18 & 18 & 5 \\
\hline & & & \multicolumn{11}{|c|}{ Rearession 3: U.S. monetarv policv surprises and $И X$} \\
\hline $\mathrm{m} 1$ & $\begin{array}{l}-0.02 \\
(0.01)\end{array}$ & $\begin{array}{l}-0.01^{\star} \\
(0.01)\end{array}$ & $\begin{array}{c}-0.11^{\star \star \star *} \\
(0.02)\end{array}$ & $\begin{array}{c}0.00 \\
(0.00)\end{array}$ & $\begin{array}{l}0.00^{* * *} \\
(0.00)\end{array}$ & $\begin{array}{l}0.01^{* \star \star *} \\
(0.00)\end{array}$ & $\begin{array}{l}0.01^{* *} \\
(0.00)\end{array}$ & $\begin{array}{l}0.01^{* \star \star *} \\
(0.00)\end{array}$ & $\begin{array}{l}0.07^{\star \star \star} \\
(0.01)\end{array}$ & $\begin{array}{c}0.00 \\
(0.01)\end{array}$ & $\begin{array}{l}0.02^{* \star} \\
(0.01)\end{array}$ & $\begin{array}{l}-0.00 \\
(0.02)\end{array}$ & $\begin{array}{c}0.08 \\
(0.06)\end{array}$ \\
\hline $\mathrm{m} 2$ & $\begin{array}{c}0.00 \\
(0.01)\end{array}$ & $\begin{array}{c}-0.38^{* * *} \\
(0.05)\end{array}$ & $\begin{array}{l}-0.07 \\
(0.06)\end{array}$ & $\begin{array}{l}0.00^{* \star} \\
(0.00)\end{array}$ & $\begin{array}{l}0.01^{* \star} \\
(0.00)\end{array}$ & $\begin{array}{l}0.04^{* *} \\
(0.02)\end{array}$ & $\begin{array}{l}0.02^{*} \\
(0.01)\end{array}$ & $\begin{array}{l}0.31^{* * \star} \\
(0.05)\end{array}$ & $\begin{array}{c}0.08^{*} \\
(0.04)\end{array}$ & $\begin{array}{l}0.03^{*} \\
(0.01)\end{array}$ & $\begin{array}{c}-0.18^{\star \star \star \star} \\
(0.06)\end{array}$ & $\begin{array}{l}-0.10 \\
(0.23)\end{array}$ & $\begin{array}{l}-0.06 \\
(0.05)\end{array}$ \\
\hline Change in $\mathrm{VX}$ & $\begin{array}{c}-0.11^{* \star \star *} \\
(0.01)\end{array}$ & $\begin{array}{c}-0.08^{\star \star \star *} \\
(0.01)\end{array}$ & $\begin{array}{c}-0.06^{\star \star \star *} \\
(0.01)\end{array}$ & $\begin{array}{l}0.00^{\star * \star *} \\
(0.00)\end{array}$ & $\begin{array}{l}0.00^{* \star} \\
(0.00)\end{array}$ & $\begin{array}{c}0.00 \\
(0.00)\end{array}$ & $\begin{array}{l}0.03^{\star \star \star \star} \\
(0.00)\end{array}$ & $\begin{array}{l}0.03^{\star \star * \star} \\
(0.01)\end{array}$ & $\begin{array}{l}0.02^{* \star} \\
(0.01)\end{array}$ & $\begin{array}{c}-0.02^{* *} \\
(0.01)\end{array}$ & $\begin{array}{c}0.02 \\
(0.01)\end{array}$ & $\begin{array}{c}-0.05^{* *} \\
(0.02)\end{array}$ & $\begin{array}{c}0.02 \\
(0.03)\end{array}$ \\
\hline Constant & $\begin{array}{l}0.11^{\star \star *} \\
(0.02)\end{array}$ & $\begin{array}{l}-0.12^{* *} \\
(0.05)\end{array}$ & $\begin{array}{c}0.08^{*} \\
(0.04)\end{array}$ & $\begin{array}{c}-0.02^{* \star \star \star} \\
(0.00)\end{array}$ & $\begin{array}{l}-0.00 \\
(0.00)\end{array}$ & $\begin{array}{l}0.02^{* \star *} \\
(0.00)\end{array}$ & $\begin{array}{l}-0.03^{*} \\
(0.01)\end{array}$ & $\begin{array}{l}0.28^{* \star *} \\
(0.04)\end{array}$ & $\begin{array}{l}0.17^{\star \star * *} \\
(0.02)\end{array}$ & $\begin{array}{l}0.14^{* \star *} \\
(0.02)\end{array}$ & $\begin{array}{l}0.10^{* *} \\
(0.04)\end{array}$ & $\begin{array}{c}-0.36^{\star \star * *} \\
(0.01)\end{array}$ & $\begin{array}{c}-0.28^{* *} \\
(0.07)\end{array}$ \\
\hline Observations & 1,306 & 812 & 175 & 993 & 726 & 140 & 1,303 & 804 & 175 & 1,031 & 713 & 143 & 81 \\
\hline R-squared & 0.12 & 0.22 & 0.29 & 0.01 & 0.07 & 0.20 & 0.05 & 0.23 & 0.27 & 0.01 & 0.03 & 0.06 & 0.04 \\
\hline Number of countries & 21 & 21 & 21 & 17 & 18 & 18 & 21 & 21 & 21 & 19 & 18 & 18 & 5 \\
\hline
\end{tabular}

Sources: Authors' calculations.

Note: This table presents results from three separate rearessions with different independent variables included. Robust standard errors in parentheses, ${ }^{* \star *} p<0.01$, ${ }^{* *} p<0.05,{ }^{*} p<0.1$. 
A second hypothesis that may explain the larger spillovers in the UMP-T phase is that other factors might have amplified or dampened the effects of monetary policy shocks. The main candidate for such factors is volatility in financial markets, which we proxy by the VIX. ${ }^{11}$

Results from regressions that include the VIX provide partial support for this hypothesis; various results stand out (Table 3). First, the coefficient on the VIX is nearly always significant in regressions including only the VIX. But second, this paper's surprise measures continue to be significant even after controlling for the VIX. The VIX must therefore be distinguished from U.S. monetary policy shocks. It contains additional information that could affect markets, such as investor sentiment and risk appetite. Third, the VIX does not explain the greater spillovers in the UMP phases relative to the CMP phase. Coefficients on the surprise measures continue to be insignificant, or on a few occasions very small, in the CMP phase across measures of asset prices and capital flows. Fourth, the VIX does explain the greater spillovers during the UMP-T phase relative to the UMP-P phase, but only following signal surprises. Indeed, coefficients on the signal factor consistently shrink during the UMP$\mathrm{T}$ phase when controlling for the VIX (but coefficients on market surprises do not change with the inclusion of the VIX). Accordingly, the UMP-T phase no longer stands out as leading to consistently larger spillovers relative to the UMP-P phase.

Two results remain unchanged. The first is that whatever the phase, signal surprises nearly always lead to larger spillovers than market surprises. And the second is that spillovers were larger and more significant during the UMP period, as opposed to the CMP period. The result is robust to controlling for the type of monetary policy shocks (first hypothesis) and for market factors (second hypothesis). It therefore seems that there may be a structural explanation for this result. One possibility is that instruments of policy matter; a loosening (or tightening) coming from asset purchases has greater spillovers than one coming from changes in interest rates.

\section{SpIllovers ACross Countries-WHY ARE They Different?}

Movements in asset prices and capital flows following U.S. monetary policy announcements differed significantly across countries. This feature of the data is perhaps best illustrated in the divergence of country responses to the shocks coming from the initial U.S. tapering talks in May and June 2013 (Figure 6).

We investigate whether emerging market characteristics explain this cross-sectional (cross-country) variation. We control for two sets of characteristics: macroeconomic and financial. Our prior is that countries with stronger macroeconomic fundamentals

\footnotetext{
${ }^{11}$ Other candidate explanations exist. The most prominent is growth in EMs. However, regressions controlling for such measures yield no clear pattern. Expected growth in China, though, seems to have affected spillovers to EMs as a whole. The higher the expected growth in China, the lower the spillovers (expected growth in China worsened during the UMP phase). Yet, because of only a relatively rough measure of growth expectations in China (the PMI), we do not dwell on this result.
} 
will experience smaller spillovers. We do not have any priors on the market variables as there may be opposing factors at play, as discussed below. ${ }^{12}$

We introduce country characteristics in the baseline regression, as standalone variables and as interaction terms. We run the following regression:

$$
\Delta y_{i t}=\alpha_{i}+\beta_{1} m 1+\beta_{2} m 2+\gamma_{1} C C_{t}+\gamma_{2} C C_{t} * m 1+\gamma_{3} C C_{t} * m 2+\varepsilon_{i t}
$$

where $C C_{t}$ stands for country characteristics, and all other variables are defined as before. We investigate whether the coefficient on the interactive terms, $\gamma_{2}$ and $\gamma_{3}$, have opposite signs as compared to the coefficients on the respective surprise factors, $\beta_{1}$ and $\beta_{2}$. If so, we conclude that the country characteristics dampens shocks; if the signs are the same, then country characteristics dampen shocks. We add all macroeconomic characteristics simultaneously. Given likely multicollinearity, we add financial variables one at a time. Because the number of explanatory variables are large, we no longer have sufficient degrees of freedom to separate the UMP phase into UMP-P and UMP-T sub-phases (doing so is less important in this section, as the goal is no longer to separate effects over time, but to explain the cross sectional variation in spillovers). Results are provided in Table $3 . .^{13}$

In the CMP phase, there are few instances when country characteristics seem to matter. (This is not surprising, as spillovers are generally small or insignificant over this phase of U.S. monetary policy). ${ }^{14}$

On the other hand, in the UMP phase, better fundamentals matter. Higher real GDP dampens spillovers (coefficients on the interactive terms are of opposite sign than on the respective surprise factors) for bond yields and foreign exchange. Moreover, a higher current account surplus (lower deficit), lower inflation and lower share of local debt held by foreigners dampen spillovers for all asset prices: equity prices, bond yields and foreign exchange (this is always true for signal surprises, and in a third of the cases for market surprises).

Market variables also play some role in determining cross-country differentiation in the UMP phase. A larger market size tends to amplify spillovers on foreign exchange, after controlling for market liquidity. The result makes sense as larger markets have two effects of opposite sign: they attract more foreign investors, thus expose themselves to

\footnotetext{
${ }^{12}$ Macroeconomic characteristics are: real GDP growth, current account surpluses, inflation and share of local debt held by foreigners. And financial characteristics are: market size as measured by market capitalization, and market liquidity captured by bid-ask spreads of the local currency bond market. Data are from IFS for the macro variables, and Bloomberg and Bankscope for the market variables.

${ }^{13}$ For exposition purposes, we do not report coefficients on the control variables, but only on the interaction terms. A more complete set of results is available from the authors upon request.

${ }^{14}$ Results are available upon request from the authors.
} 
greater volatility, but are also more liquid, and thus dampen volatility. Indeed, results suggest that countries with less liquid markets have larger spillovers on equity prices.

Once again, signal-as opposed to market-surprises stand out, as they lead to greater investor differentiation. As discussed earlier, the signal factor may be more closely related to fundamentals of monetary policy, and thus induce investors to respond to fundamentals in their portfolio decisions. Instead, market surprises affect risk perceptions more generally, and thus might lead to more wide-spread-less differentiated-reallocations of portfolios across countries and asset classes.

Figure 6. Asset Price and Capital Flow Movements Across Countries (May and June 2013)

Capital flows (bond and equity)

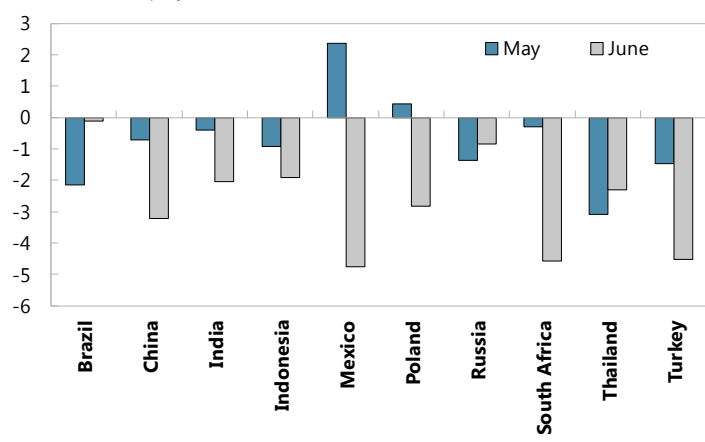

Equity prices

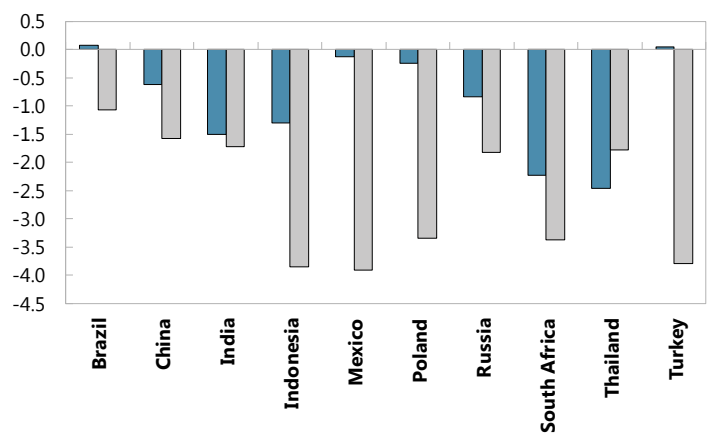

Exchange rate

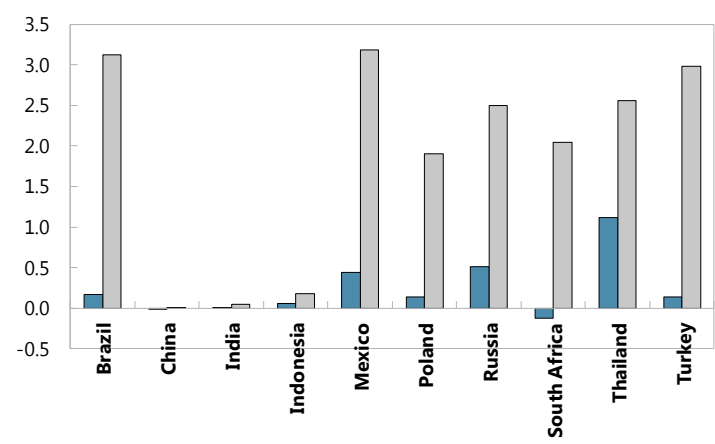

10-year bond yields

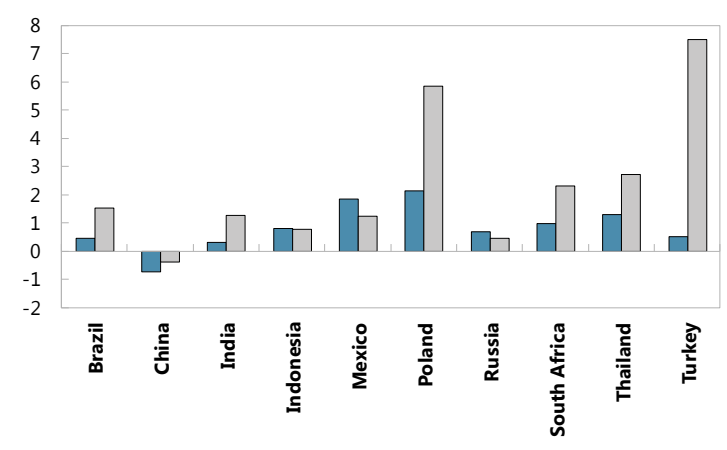

Sources: Haver Analytics, EPFR, Datastream, and authors' calculations. 


\section{Table 3. Amplifiers or Dampeners of Spillovers, Role of Country Characteristics}

\begin{tabular}{|c|c|c|c|c|c|}
\hline Variables & Equity & Bond Yields & Exchange Rates & Equity Flows & Bond Flows \\
\hline $\mathrm{m} 1$ * Expected GDP growth & $\begin{array}{l}-0.00 \\
(0.00)\end{array}$ & $\begin{array}{l}-0.00^{* *} \\
(0.00)\end{array}$ & $\begin{array}{c}-0.00^{* *} \\
(0.00)\end{array}$ & $\begin{array}{c}-0.01^{* * *} \\
(0.00)\end{array}$ & $\begin{array}{c}0.00 \\
(0.01)\end{array}$ \\
\hline $\mathrm{m} 2$ * Expected GDP growth & $\begin{array}{c}0.03 \\
(0.03)\end{array}$ & $\begin{array}{l}-0.00^{* *} \\
(0.00)\end{array}$ & $\begin{array}{c}-0.06^{\star * *} \\
(0.01)\end{array}$ & $\begin{array}{l}-0.03 \\
(0.03)\end{array}$ & $\begin{array}{l}0.17^{*} \\
(0.09)\end{array}$ \\
\hline $\mathrm{m} 1{ }^{*}$ Current account & $\begin{array}{l}0.00^{*} \\
(0.00)\end{array}$ & $\begin{array}{l}-0.00 \\
(0.00)\end{array}$ & $\begin{array}{l}-0.00^{*} \\
(0.00)\end{array}$ & $\begin{array}{l}-0.00 \\
(0.00)\end{array}$ & $\begin{array}{c}0.00 \\
(0.00)\end{array}$ \\
\hline $\mathrm{m} 2{ }^{*}$ Current account & $\begin{array}{l}0.01^{* *} \\
(0.01)\end{array}$ & $\begin{array}{l}-0.00^{* *} \\
(0.00)\end{array}$ & $\begin{array}{c}-0.01^{* * *} \\
(0.00)\end{array}$ & $\begin{array}{c}0.01 \\
(0.01)\end{array}$ & $\begin{array}{c}0.02 \\
(0.03)\end{array}$ \\
\hline $\mathrm{m} 1{ }^{*}$ inflation & $\begin{array}{l}-0.01 \\
(0.01)\end{array}$ & $\begin{array}{l}-0.00^{*} \\
(0.00)\end{array}$ & $\begin{array}{l}\mathbf{0 . 0 1}^{* *} \\
(0.01)\end{array}$ & $\begin{array}{l}-0.01 \\
(0.01)\end{array}$ & $\begin{array}{l}-0.04 \\
(0.05)\end{array}$ \\
\hline $\mathrm{m} 2$ * inflation & $\begin{array}{l}-0.26^{* *} \\
(0.11)\end{array}$ & $\begin{array}{l}-0.00 \\
(0.01)\end{array}$ & $\begin{array}{l}\mathbf{0 . 1 3} 3^{* *} \\
(0.06)\end{array}$ & $\begin{array}{l}-0.15 \\
(0.12)\end{array}$ & $\begin{array}{c}0.23 \\
(0.53)\end{array}$ \\
\hline $\mathrm{m} 1{ }^{*}$ market capitalization & $\begin{array}{c}0.00 \\
(0.00)\end{array}$ & $\begin{array}{l}-0.00 \\
(0.00)\end{array}$ & $\begin{array}{l}-0.00 \\
(0.00)\end{array}$ & $\begin{array}{c}0.00 \\
(0.00)\end{array}$ & $\begin{array}{l}-0.00 \\
(0.00)\end{array}$ \\
\hline $\mathrm{m} 2{ }^{*}$ market capitalization & $\begin{array}{c}0.00 \\
(0.00)\end{array}$ & $\begin{array}{l}-0.00 \\
(0.00)\end{array}$ & $\begin{array}{l}\mathbf{0 . 0 0} \\
(0.00)\end{array}$ & $\begin{array}{c}0.00 \\
(0.00)\end{array}$ & $\begin{array}{l}-0.00 \\
(0.00)\end{array}$ \\
\hline $\mathrm{m} 1{ }^{*}$ local debt held by foreigners & $\begin{array}{c}-0.00^{* * *} \\
(0.00)\end{array}$ & $\begin{array}{l}\mathbf{0 . 0 0 * * *} \\
(0.00)\end{array}$ & $\begin{array}{c}\mathbf{0 . 0 0} 0^{* * *} \\
(0.00)\end{array}$ & $\begin{array}{l}-0.00 \\
(0.00)\end{array}$ & $\begin{array}{c}0.00 \\
(0.00)\end{array}$ \\
\hline $\mathrm{m} 2$ * local debt held by foreigners & $\begin{array}{c}-0.02^{* *} \\
(0.01)\end{array}$ & $\begin{array}{c}0.00 \\
(0.00)\end{array}$ & $\begin{array}{c}\mathbf{0 . 0 2}^{* * *} \\
(0.00)\end{array}$ & $\begin{array}{l}-0.01 \\
(0.01)\end{array}$ & $\begin{array}{c}0.00 \\
(0.01)\end{array}$ \\
\hline $\mathrm{m} 1$ * bid ask spread & $\begin{array}{c}-0.38^{\star * *} \\
(0.11)\end{array}$ & $\begin{array}{c}0.02 \\
(0.03)\end{array}$ & $\begin{array}{c}0.06 \\
(0.10)\end{array}$ & $\begin{array}{l}-0.04 \\
(0.12)\end{array}$ & $\begin{array}{c}0.49 \\
(0.54)\end{array}$ \\
\hline $\mathrm{m} 2$ * bid ask spread & $\begin{array}{l}-2.43^{* *} \\
(1.15)\end{array}$ & $\begin{array}{l}0.22^{*} \\
(0.11)\end{array}$ & $\begin{array}{c}0.13 \\
(0.94)\end{array}$ & $\begin{array}{l}-2.38 \\
(2.37)\end{array}$ & $\begin{array}{c}4.06 \\
(3.65)\end{array}$ \\
\hline $\begin{array}{l}\text { Country level controls } \\
\text { FF }\end{array}$ & $\begin{array}{l}\mathrm{Y} \\
\mathrm{Y}\end{array}$ & $\begin{array}{l}\mathrm{Y} \\
\mathrm{Y}\end{array}$ & $\begin{array}{l} \\
Y\end{array}$ & $\begin{array}{l} \\
Y \\
Y\end{array}$ & $\begin{array}{l}\mathrm{Y} \\
\mathrm{Y}\end{array}$ \\
\hline Observations & 914 & 815 & 906 & 805 & 271 \\
\hline R-squared & 0.145 & 0.0996 & 0.217 & 0.0332 & 0.0464 \\
\hline Number of countries & 21 & 18 & 21 & 18 & 11 \\
\hline
\end{tabular}

Source: Authors' calculations.

Note: This table illustrates the country characteristics that, when higher, either dampen (bold-italics) or amplify (bold) effects of U.S. monetary policy shocks (either market or signaling--see text for details) on the three asset prices noted at the top. Robust standard errors in parentheses ${ }^{* *} p<0.01,{ }^{* *} p<0.05,{ }^{*} p<0.1$

\section{Conclusion ANd Policy Implications}

Given the dominance of the U.S. economy and finance in global markets, spillovers from U.S monetary policy to the rest of the world is not surprising. But they are mostly a recent phenomenon, having remained subdued before the global financial crisis. This section revisits the results highlighted in this paper, and for each draws out specific policy implications.

Unconventional monetary policies had larger spillovers per unit of surprise than conventional policies. The difference does not seem to stem from a change in the type of 
shocks (size, sign or turning points), nor from the effect of greater market volatility (uncertainty) during the UMP period. The reason seems to be more structural, tied to the particular instruments used during the UMP period, and perhaps to the liquidity that was created. This finding seems to underscore another cost of hitting the zero lower bound, and thus another reason to adopt policies in good times, such as appropriate prudential regulation, so as to minimize risks of hitting the zero lower bound in bad times. Some evidence also points to the conjunctural cycle of emerging market economies as affecting spillovers; these are greater the weaker the growth prospects in EMs, and in particular in China. Thus, countries and investors should monitor the external economic environment to prepare themselves for potential spillovers.

Characteristics of recipient countries also matter for spillovers. Better fundamentals and more liquid markets help dampen the effects of U.S. monetary policy shocks. This suggests a shared responsibility in minimizing negative spillovers, and should encourage EMs to improve their fundamentals as much as possible before considering more intrusive and distortion-creating measures such as foreign exchange interventions and capital controls, even though they may be effective in the short run.

Spillovers are more ubiquitous and larger if stemming from signal surprises. The result is robust across measures of asset prices and capital flows, across phases of monetary policy, and to controls such as the VIX. This is good news, as the signaling channel is better understood by central banks, and can be better managed through clear communication. The U.S. Fed and other influential central banks should, therefore, be able to minimize the source of shocks that lead to global spillovers.

At the same time, even though market surprises have smaller spillovers, their effects are less differentiated across countries and thus more unpredictable. To minimize the effects of market surprises, the U.S. Fed and other advanced economy central banks should focus on minimizing shocks to long-term bond yields when they exit from unconventional monetary policies. This might be done, for instance, by not selling outright the assets they have accumulated, or at least doing so in a very predictable and mechanical fashion. 


\begin{tabular}{|c|c|c|c|c|}
\hline \multicolumn{5}{|c|}{ APPENDIX } \\
\hline able 1. & S. Monetar & $\begin{array}{l}\text { Policy } \\
\text { Market } \\
\text { surprise } \\
\text { (m1) }\end{array}$ & $\begin{array}{l}\text { Annol } \\
\text { Signal } \\
\text { surprise } \\
(\mathrm{m} 2) \\
\end{array}$ & cements and Surprises \\
\hline \multicolumn{5}{|c|}{ CMP } \\
\hline $12 / 11 / 2001$ & & -3.3 & -2.8 & $\begin{array}{l}\text { Further } 25 \text { bps cut, bringing Federal } \\
\text { Funds to } 40 \text { years low. }\end{array}$ \\
\hline $6 / 30 / 2004$ & & -3.2 & -5.6 & $\begin{array}{l}\text { Though } 25 \text { bps hike is first in nearly } 4 \\
\text { years, markets were expecting more as } \\
\text { core CPI had risen by } 3.3 \text { percent in the } \\
\text { months leading to the decision (see } \\
\text { money.cnn.com } / 2004 / 06 / 30 / \text { news/eco } \\
\text { nomy/fed_decision/) }\end{array}$ \\
\hline $6 / 29 / 2006$ & & -2.0 & -3.0 & $\begin{array}{l}25 \text { bps hike surprises market } \\
\text { participants, some of which had been } \\
\text { expecting a stronger tightening of } \\
\text { policy (see } \\
\text { http://money.cnn.com/2006/06/29/ma } \\
\text { rkets/stockswatch/index.htm?section= } \\
\text { money_topstories). }\end{array}$ \\
\hline \multicolumn{5}{|c|}{ UMP } \\
\hline $11 / 25 / 2008$ & $\begin{array}{l}\text { Asset purchases } \\
\text { (LSAP1) }\end{array}$ & -22.9 & -1.0 & $\begin{array}{l}\text { Fed announces purchases up to US\$100 } \\
\text { billion in agency debt and US\$500 } \\
\text { billion in MBS. }\end{array}$ \\
\hline $12 / 16 / 2008$ & Forward Guidance & -14.4 & -2.0 & $\begin{array}{l}\text { The FOMC "anticipates...exceptionally } \\
\text { low levels of th efederal funds rate for } \\
\text { some time." }\end{array}$ \\
\hline $3 / 18 / 2009$ & $\begin{array}{l}\text { Bond purchases } \\
\text { (LSAP1) }\end{array}$ & -40.6 & -3.5 & $\begin{array}{l}\text { Fed announces purchases of longer- } \\
\text { term Treasury securities (US\$300 } \\
\text { billion) over the next six months. }\end{array}$ \\
\hline $11 / 3 / 2010$ & $\begin{array}{l}\text { Bond purchases } \\
\text { (LSAP2) }\end{array}$ & 9.9 & -3.4 & $\begin{array}{l}\text { The FOMC "intends to purchase a } \\
\text { further US\$600 longer term Treasury } \\
\text { securities by the end of the second } \\
\text { quarter of } 2011 \text { (announcement diluted } \\
\text { by earlier Jackson Hole speech). }\end{array}$ \\
\hline $9 / 13 / 2012$ & Forward Guidance & -2.7 & -1.5 & $\begin{array}{l}\text { The FOMC "will continue to maintian } \\
\text { interest rates extremely low until at } \\
\text { least mid-2015." }\end{array}$ \\
\hline $22 / 05 / 2013$ & Taper talk & 9.9 & -1.2 & $\begin{array}{l}\text { Bernanke (testimony to Congress): "In } \\
\text { the next few meetings, we could take a } \\
\text { step down in our pace of purchase." }\end{array}$ \\
\hline $19 / 06 / 2013$ & Taper talk & 12.1 & 0.7 & $\begin{array}{l}\text { Bernanke (press conference): "The } \\
\text { central bank may start dialing down its } \\
\text { unprecedented bond-buying program } \\
\text { this year and end it entirely in mid- } \\
2014 \text { if the economy finally achieves } \\
\text { the sustainable growth the Fed sought } \\
\text { since the recession ended in 2009." }\end{array}$ \\
\hline
\end{tabular}

CInternational Monetary Fund. Not for Redistribution 
Figure 2. Asset Price and Capital Flow Movements Across Time ${ }^{15}$ (CMP, UMP-P, and UMP-T Phases, January 2000-March 2014)

\author{
Impacts on EM Equity Prices
}

CMP: Jan '00-Jul '08

Purchases: Nov ‘08-May ‘13

Taper: May '13-Mar '14
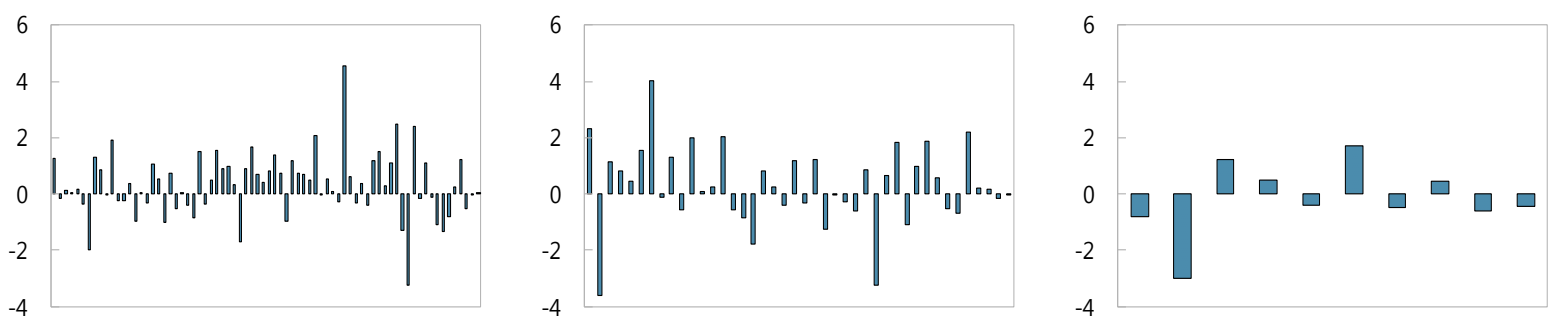

\title{
Impacts on EM Bond Yields
}

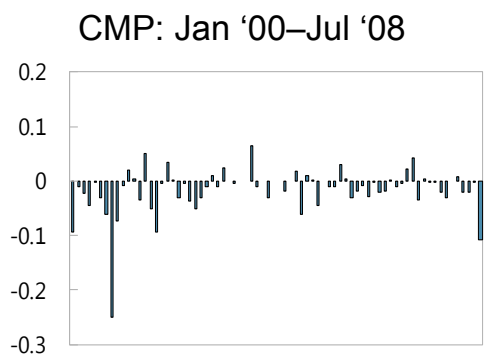

Purchases: Nov '08-May '13
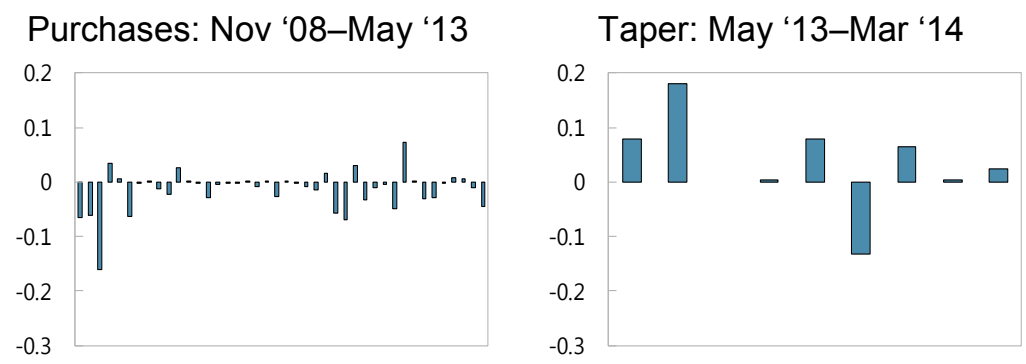

Impacts on EM Exchange Rates

CMP: Jan ‘00-Jul '08

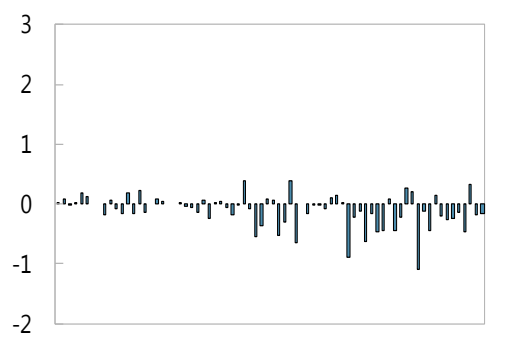

Purchases: Nov '08-May '13

Taper: May '13-Mar '14
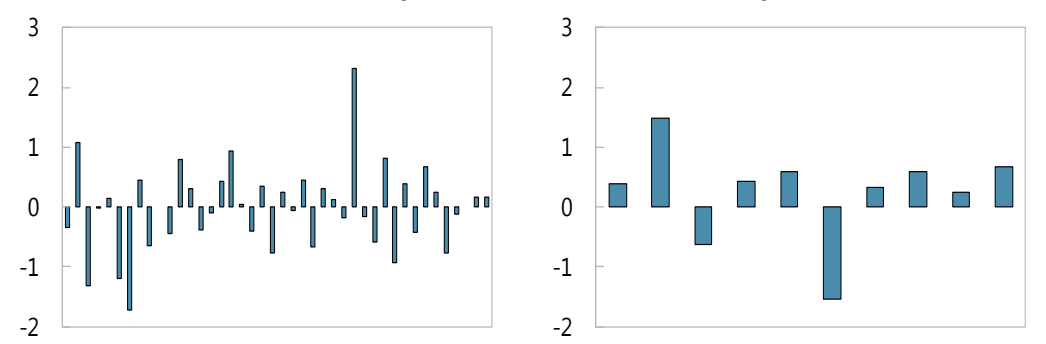

\footnotetext{
${ }^{15}$ Figure 1 depicts changes in asset prices and capital flows in emerging markets following U.S. monetary policy surprises. Each bar in the figure represents the average effect over 21 EM countries in our sample on each FOMC announcement day. The figure is split in five panels. The first three represent asset price movements - equity prices, bond yields and nominal effective exchange rates - and the last two capture capital (portfolio) flows into equity and bonds. Asset prices are taken from Bloomberg as daily closing prices. And capital flows data are weekly (unfortunately daily data does not exist), and come from EPFR Global, covering equity and bond investments by a collection of asset managers.
} 
Figure 2. Asset Price and Capital Flow Movements Across Time ${ }^{16}$ (CMP, UMP-P, and UMP-T Phases, January 2000-March 2014), continued

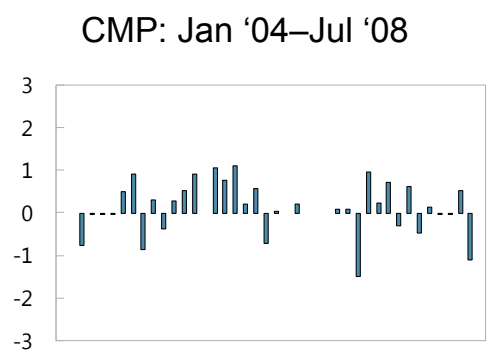

\author{
Impacts on EM Equity Flows
}

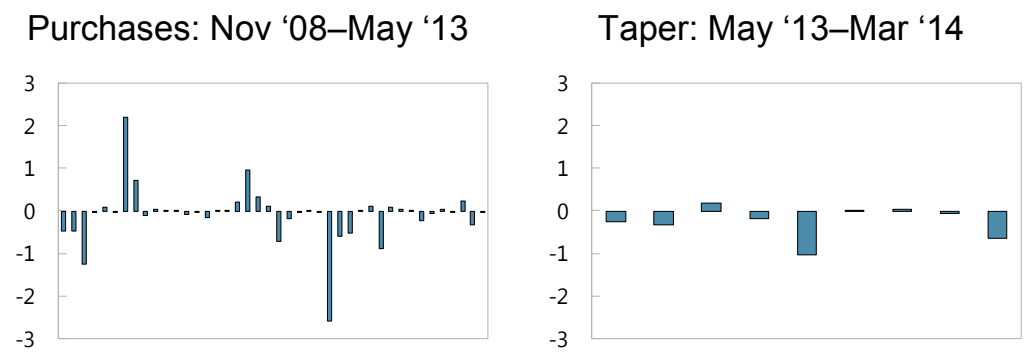

Impacts on EM Bond Yields

CMP: Jan ‘04-Jul ‘08

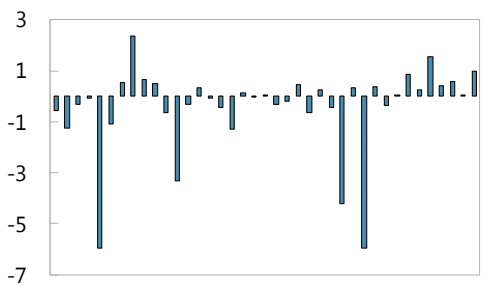

Purchases: Nov '08-May '13

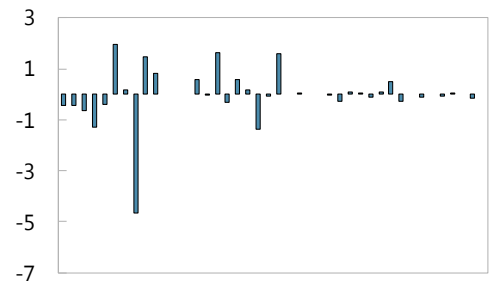

Taper: May '13-Mar '14

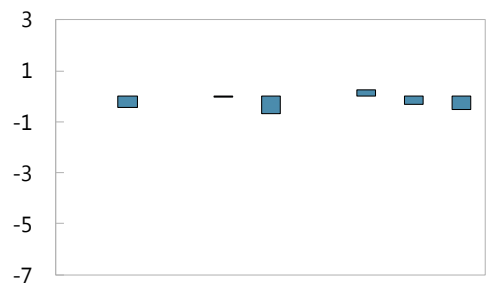

Sources: Bloomberg, Thomson Reuters Datastream, EPFR Global and authors's calculations Note: As shown in Figure 2, response of EM asset prices and capital flows changed markedly during the UMP-T phase. This is especially true of bond yields, and foreign exchange responses that are much more one-sided (and larger in the case of bond yields) than during the UMP-P and CMP phases. The same is true of capital flows (both equity and bond flows) that show nearly ubiquitous outflows from emerging market economies, whether or not U.S. monetary policy shocks were positive or negative.

\footnotetext{
${ }^{16}$ Figure 1 depicts changes in asset prices and capital flows in emerging markets following U.S. monetary policy surprises. Each bar in the figure represents the average effect over 21 EM countries in our sample on each FOMC announcement day. The figure is split in five panels. The first three represent asset price movements - equity prices, bond yields and nominal effective exchange rates - and the last two capture capital (portfolio) flows into equity and bonds. Asset prices are taken from Bloomberg as daily closing prices. And capital flows data are weekly (unfortunately daily data does not exist), and come from EPFR Global, covering equity and bond investments by a collection of asset managers.
} 


\section{REFERENCES}

Anderson, T. W., 1984, An Introduction to Multivariate Statistical Analysis, $2^{\text {nd }}$ ed. New York: Wiley.

Adrian, T., R. Crump, and E. Moench, 2013, "Pricing the Term Structure With Linear Regressions," Journal of Financial Economics, Elsevier, Vol. 110, Issue 1, pp 110138.

Ahmed, S. and A. Zlate 2013, "Capital Flows to Emerging Market Economies: A Brave New World," International Finance Discussion Papers No. 1081, Federal Reserve Board,.

Bauer M.D., and C. J. Neely 2012, "International Channels of the Fed's Unconventional Monetary Policy," Federal Reserve Bank of St. Louis Working Paper No. 28.

Bauer, M.D., and G. D. Rudebusch 2014, "The Signaling Channel for Federal Reserve Bond Purchases," International Journal of Central Banking , Vol. 10, Issue 3, pp. 233-289, September.

Bernanke, B. and K. Kuttner 2005, "What Explains the Stock Market's Reaction to Federal Reserve Policy?" Journal of Finance, 60, Issue 3, 1221-1257.

Bowman, D., J. Londoño, and H. Sapriza, 2014, "U.S. Unconventional Monetary Policy and Transmission to Emerging Market Economics," International Finance Discussion Papers No. 1109, Board of Governors of the Federal Reserve System.

Campbell, J. R., C. L. Evans, J.D.M. Fisher, and A. Justiniano, 2012, "Macroeconomic Effects of Federal Reserve Forward Guidance," Brookings Papers on Economic Activity, Economic Studies Program, The Brookings Institution, Vol. 44, Issue 1 (Spring), pp. 1-80.

Chen, Q., A. Filardo, D. He, and F. Zhu, 2012, "International Spillovers of Central Bank Balance Sheet Policies," BIS Working Paper No. 66.

Chen, J., T. Mancini-Griffoli, and T. Saadi-Sedik, 2014, (forthcoming), "Macroeconomic Effects of Large Scale Asset Purchase: Do Channels of Transmission Matter?" IMF Working Paper.

Cochrane, J. F. 2005, Asset Pricing. Princeton NJ: Princeton University Press.

D’Amico, S., W. English, D. López-Salido, and E. Nelson, 2012, "The Federal Reserve's Large-scale Asset Purchase Programmes: Rationale and Effects," Economic Journal, Royal Economic Society, Vol. 122, Issue 564, pp. F415-F446, November. 
De Pooter, M., P. Robitaille, I. Walker, and M. Zdinak, 2014, “Are Long-Term Inflation Expectations Well Anchored in Brazil, Chile, and Mexico?," International Finance Discussion Papers No. 1098, Board of Governors of the Federal Reserve System.

Eichengreen, B., and P. Gupta, 2014, "Tapering Talk: The Impact of Expectations of Reduced Federal Reserve Security Purchases on Emerging Markets," MPRA Paper NO. 53040, University Library of Munich, Germany.

Forbes, K. and F. Warnock 2011, “Capital Flow Waves: Surges, Stops, Flight, and Retrenchment," NBER Working Paper 17351.

Fratzscher, M., 2011, “Capital Flows, Push Versus Pull Factors and the Global Financial Crisis,” NBER Working Paper 17357.

Fratzscher, M., M. Lo Duca, and R. Straub, 2012, “A Global Monetary Tsunami? On the Spillovers of U.S. Quantitative Easing,” CEPR Working Paper 9195.

Glick, R. and S. Leduc, 2012, "Central Bank Announcements of Asset Purchases and the Impact on Global Financial and Commodity Markets," Journal of International Money and Finance, 31, 2078-2101.

Glick, R. and S. Leduc, 2013, "The Effects of Unconventional and Conventional U.S. Monetary Policy on the Dollar," Federal Reserve Bank of San Francisco Working Paper No. 11.

Ghosh, A, J Kim, MS Qureshi, and J Zalduendo, 2012, “Surges”, IMF Working Paper 12/22.

Gilchrist, Simon, Vivian Yue, and Egon Zakrajsek, 2014, “U.S. Monetary Policy and Foreign Bond Yields," Mimeo, Federal Reserve Board of Governors.

Gorsuch, R. L. , 1983, Factor Analysis, 2nd edition, Hillsdale: Erlbaum.

Gurkaynak, R., B. Sack, and E. Swanson, 2005, "Do Actions Speak Louder Than Words? The Response of Asset Prices to Monetary Policy Actions and Statements," International Journal of Central Banking, May.

Gurkaynak, R., B. Sack, and E. P. Swanson, 2007, "Market-Based Measures of Monetary Policy Expectations," Journal of Business and Economic Statistics, American Statistical Association, Vol. 25, pages 201-212, April.

Hausman, J. and J. Wongswan, 2011, “Global Asset Prices and FOMC Announcements.” Journal of International Money and Finance, Vol. 30, Issue 3, 547-571.

Kuttner, Kenneth, "Monetary Policy Surprises and Interest Rates: Evidence from the Fed Funds Futures Market," Journal of Monetary Economics, 2001, Vol. 47, 523-544. 
Joslin, S., K. Singleton and H. Zhu, 2010, "A New Perspective on Gaussian Dynamic Term Structure Models," Review of Financial Studies, Vol. 24, 926-970.

Kim, D. H. and J. H. Wright, 2005, “An Arbitrage-Free Three-Factor Term Structure Model and the Recent Behavior of Long-Term Yields and Distant-Horizon Forward Rates," Finance and Economics Discussion Series No. 33, Federal Reserve Board of Governors.

Krishnamurthy, A., and A. Vissing-Jorgensen, 2011, "The Effects of Quantitative Easing on Interest Rates: Channels and Implications for Policy," Brookings Papers on Economic Activity, Fall.

Lane, P. R., and G.M. Milesi-Ferretti, 2004, "The Transfer Problem Revisited: Net Foreign Assets and Real Exchange Rates," The Review of Economics and Statistics, Vol. 86, Issue 4, pages 841-857, November.

Mishra, P., K. Moriyama, P. N’Diaye, and L. Nguyen, 2014, “Impact of Fed Tapering Announcements on Emerging Markets," IMF Working Paper 14/109.

Moore, J., S. Nam, M. Suh and A. Tepper, 2013, "Estimating the Impacts of U.S. LSAPs on Emerging Market Economies' Local Currency Bond Markets," FRBNY Staff Report No. 595, January.

Neely, C., 2010, “The Large-Scale Asset Purchases had Large International Effects,” Federal Reserve Bank of St. Louis Working Paper 2010-018C.

Reinhart, C, and V Reinhart, 2008, "Capital Flow Bonanzas: An Encompassing View of the Past and Present," NBER Working Paper 14321.

Rigobon, R. and B. Sack, 2003, "Identification Through Heteroskedasticity," Review of Economics and Statistics, 85, 777-792.

Rigobon, R. and B. Sack, 2004, "The Impact of Monetary Policy on Asset Prices," Journal of Monetary Economics, 51, 1553-1575.

Rogers, J., C. Scotti, and J. Wright, 2013, "Evaluating Asset-Market Effects of Unconventional Monetary Policy: A Cross-Country Comparison." Federal Reserve Board Working Paper.

Stein, J., 2012, “Evaluating Large Scale Asset Purchases,” Speech given at the Brookings Institution, Washington DC, October. (available online: http://www.federalreserve.gov/newsevents/speech/stein20121011a.htm)

Woodford, M., 2012, "Methods of Policy Accommodation at the Interest-Rate Lower Bound," presented at the Jackson Hole symposium, August 2012. 
Wright, J. H., 2011, "What Does Monetary Policy do to Long-Term Interest Rates at the Zero Lower Bound?" NBER Working Paper 17154. 